\title{
The monetary value of disability-adjusted-life-years lost in Kenya in 2017
}

Rose Nabi Deborah Karimi Muthuri ${ }^{1}$

Joses M. Kirigia ${ }^{2 *}$

${ }^{1}$ School of Health Systems and Public Health, University of Pretoria, Private bag X20, Hatfield 0028, Pretoria, South Africa

${ }^{2}$ African Sustainable Development Research Consortium (ASDRC), Nairobi, Kenya

*Corresponding Author: Professor Joses Muthuri Kirigia, ASDRC, P.O. Box 699400100 GPO, Nairobi, Kenya. Telephone: +254720664167. Email: muthurijoses68@gmail.com 


\section{Abstract}

Diseases and injuries exert a heavy health and economic burden on Kenya. The specific objectives of this study were: (a) to estimate the monetary value of disability-adjusted-life-years (DALYs) lost from all causes in 2017 with ongoing implementation of United Nations Sustainable Development Goal SDG 3; and (b) to estimate the reductions in monetary value of DALY losses in Kenya assuming diseases and injuries related to SDG3 targets are achieved by 2030. A variant of human capital (or net output) analytical framework was applied to monetarily value DALYs lost from 166 diseases and injuries. The 17.9 million DALYs lost in Kenya in 2017 had a total monetary value of Int\$ 67,012,790,388. Approximately, $56.64 \%$ of the monetary value of DALYs lost emanated from communicable, maternal, neonatal, and nutritional diseases; $35.94 \%$ from non-communicable diseases; and $7.42 \%$ from injuries. We estimate that full attainment of the five SDG 3 targets would lead to a Int 21.52 billion (45.42\%) decrease in the SDG3-related monetary value of DALYs lost by 2030. There is urgent need for health policy-makers to use this kind of evidence when advocating among public and private sectors for increased spending on health development.

Keywords: Diseases, disability-adjusted-life-year, gross domestic product, human capital approach, monetary value

Word Count: 6,753 


\section{Introduction}

Kenya is one of the six partner states of the East African Community (EAC) regional intergovernmental organisation (East African Community, 2019). It has a population of 49.364 million people, i.e. $27.6 \%$ of the EAC population (International Monetary Fund, 2019). The country has a total gross domestic product (GDP) of International Dollars (Int\$) 192.338 billion; and a GDP per capita of Int\$3 896.3.

In 2017, Kenya lost a total of 17,856,955 disability-adjusted-life-years (DALY) from all causes (Global Burden of Disease Collaborative Network, 2017). Out of which, 56.64\% resulted from communicable, maternal, neonatal, and nutritional diseases (CMNN); 35.94\% from noncommunicable diseases (NCD); and 7.42\% from injuries. Figure 1 portrays the distribution of DALYs across 20 age groups.

\section{"[insert Figure 1.]"}

About $38.75 \%$ of the DALYs were lost among children aged 14 years and below; $49.08 \%$ of the DALY loss occurred among adults aged between 15 years and 59 years; and $12.18 \%$ of the DALY loss were borne by the elderly, i.e. those aged 60 years and above.

The heavy loss of DALYs in Kenya might be attributed to two systemic weaknesses. Firstly, the inefficiently performing national health system. Kenya's health system consists of a total of 6655 health facilities; which includes 3384 (50.8\%) owned by the government and 3271 (49.2\%) by the private sector (World Health Organization, 2017a). Out of the total number of health facilities, $50.3 \%$ are health posts, $39.9 \%$ health centres, $9.4 \%$ district hospitals, $0.2 \%$ provincial hospitals and $0.1 \%$ national referral hospitals. There are 7.553 health posts per 100,000 population; 5.986 health centres per 100,000 population; 1.414 district hospitals per 100,$000 ; 0.036$ provincial hospitals per 100,000 population; and 0.016 national referral hospitals per 100,000 population (World Health Organization, 2017a).

Kenya has a health workforce density of 2.0 medical doctors per 10000 population; 15.4 nursing and midwifery personnel per 10000 population; 0.2 dentists per 10000 population; 0.5 pharmacists per 10000 population (World Health Organization, 2019a). This is lower than the global health workforce density of 15.1 medical doctors per 10000 population; and 34.8 nursing and midwifery personnel per 10000 population.

Masters et al (Masters et al., 2014) facility surveys of pharmaceutical availability across levels of care in Kenya found $18 \%$ of essential medicines were stocked out in referral hospitals; $26 \%$ were stocked out in district hospitals; $29 \%$ were stocked out in sub-district hospitals; $33 \%$ were stocked out in health centres; and 39\% were stocked out in dispensaries.

In 2016, per capita total current health expenditure on health (CHE) in Kenya was US\$ 66 (WHO, 2019b). Approximately, US\$ 24 per capita was from domestic general government health expenditure; US\$29.4 per capita from domestic private health expenditure; and US\$ 12.9 per capita from external health expenditure. Kenya CHE was below the range of US\$76 (minimum) and US\$ 342 (maximum) per person per year of health systems investment 
recommended for attaining health sustainable development goal (SDG) 3 (Stenberg et al., 2017).

Secondly, sub-optimal coverage of systems that provide services for addressing social determinants of health, e.g. education, food and nutrition, housing, water, sanitation and physical security. Due to inadequate nutrition, the prevalence of stunting and wasting in children under 5 years were $26.2 \%$ and $4.2 \%$, respectively (WHO, 2019a). The literacy rate among adults (ages 15 and older) is $78.7 \%$; meaning $21.3 \%$ are illiterate (United Nations Development Programme, 2018). About 5.3\% of households live in shanties / slums, i.e. informal shelter built with temporary building materials (Republic of Kenya, 2013). The population using improved drinking water sources is $58.5 \%$; and thus, $41.5 \%$ of the population use water that is not protected from contamination from faecal matter. A meagre $29.8 \%$ of the population use improved sanitation facilities which hygienically separate human excreta from human contact (United Nations Development Programme, 2018). Only 14\% of population primarily relies on clean fuels for cooking, heating and lighting (World Health Organization, 2019a). About 11.5\% of labour force population (ages 15 and older) is not in paid employment or self-employed (United Nations Development Programme, 2018). In the perceptions of individual well-being survey, $54 \%$ of females and $64 \%$ of males indicated they felt safe; while the reported homicide rate was 4.9 per 100,000 people (United Nations Development Programme, 2018).

As a result of under-investment in national health system, Kenya's universal health coverage (UHC) index was 57\%, implying essential health services coverage gap of $43 \%$. The tracer indicators of the essential health services include reproduction, maternal, newborn and child health; infectious diseases; noncommunicable diseases; and services capacity and access (World Health Organization, 2019a). This calls for unrelenting evidence-based advocacy within the Kenyan government, the private sector and the external development partners to increase investments into the national health system and the other systems that address social determinants of health.

Some economically developed and developing countries used monetary value of DALY evidence to make a case for increased investment into health system and health programmes interventions. For example, Lee et al (2019) estimated the economic burden of 238 diseases and 22 injuries in Korea in 2015 at US\$ 133.7 billion, which consisted of direct cost of US\$ 65.5 billion and indirect cost of US\$ 68.2 billion. Schofield et al (2019) estimated the indirect costs of ischemic heart disease to 45-64 Australian workers, government and society to be US\$755 million in 2015 and projected to increase US\$1082 million in 2030. Another study estimated the total cost of traumatic brain injury in the Netherlands at USD \$433.8 million per year (Scholten, Haagsma, Panneman, van Beeck \& Polinder, 2014). A study in Bulgaria calculated monetary value of DALYs lost from mild, moderate and severe chronic obstructive pulmonary disease (COPD) to be Euro 3596.52, Euro 34204.01 and Euro 51,332.20 per patient, respectively (Tachkov, Kamusheva, Pencheva \& Mitov, 2017).

Kirigia and Mwabu (2018) estimated non-health GDP losses associated with DALYs lost among $15-59$ year olds in Kenya in 2015 to be Int 29.8 billion. An earlier study estimated the indirect cost of DALYs lost among the elderly in Kenya in 2015 to be Int $\$ 7,088,274,986$, i.e. 3,167 per 
DALY (Kirigia, Mburugu \& Huka, 2017). To date no study in Kenya has attempted to estimate total monetary value of DALYs lost from all causes and among all the age groups.

The specific objectives of this study were: (a) to estimate the monetary value of DALYs lost from all causes and among all age groups in 2017 with ongoing implementation of United Nations Sustainable Development Goal (SDG) 3; and (b) to estimate the reductions in monetary value of DALY losses in Kenya assuming diseases and injuries related to SDG3 targets are achieved by 2030.

\section{Methods}

\section{Disability-adjusted-life-year}

Murray (Murray, 1994) defines the DALY as the sum of potential years of life lost (PYLL) to premature death and the years lived with a disability (YLD). The Institute for Health Metrics and Evaluation (IHME) database contains information on the number of DALYs lost in Kenya in 2017 from 166 diseases and injuries (Global Burden of Disease Collaborative Network, 2017).

Since the ministry of finance policy-makers and majority of private sector Chief Executive Officers are not public health specialists they have a difficult understanding public health indices such as the DALY. This puts the health sector policy-makers at a disadvantage when advocating for sustaining (or increasing) resource allocations to health sector as opposed to the so-called 'economically productive' sectors (World Health Organization, 2006). Therefore, the current study attempts to convert the DALYs into their monetary equivalents to enable health sector policy-makers use the language that those who control public and private sector budgets understand.

\section{Estimation of monetary value of DALYs Lost in Kenya in 2017}

The Organisation for Economic Cooperation and Development (OECD) defines human capital as "The knowledge, skills, competencies and attributes (including physical, emotional and mental health) embodied in individuals that facilitate the creation of personal, social and economic well-being" (p.18) (OECD, 2001). Premature mortality and non-fatal disability from any disease or injury erodes the health stock of Kenyans, and hence, their human capital.

Over 300 years ago Sir William Petty pioneered application of the human capital approach (HCA) in valuation of human lives (Petty, 1699). Since then, Fein (Fein, 1958), Mushkin and Collings (Mushkin \& Collings, 1959), Weisbrod (Weisbrod, 1971), Landefeld and Seskin (Landefeld \& Seskin, 1982), Chisholm et al (Chisholm, Stanciole, Edejer \& Evans, 2010) and WHO (WHO, 2009) further refined the theoretical underpinning of the HCA.

We adapted the variant of human capital (or net output) analytical framework developed and applied in monetary valuation of DALYs lost among the 15-59 year olds (Kirigia \& Mwabu, 2018) and the elderly (Kirigia, Mburugu \& Huka, 2017) in Kenya in 2015; and subsequently, to value the DALYs lost in 2015 within the Arab Maghreb Union (Muthuri, Muthuri \& Kirigia, 
2018 ), the Central African Economic and Monetary Community (Kirigia, Muthuri \& Gitonga, 2019), and the East African Community (Kirigia \& Mwabu, 2018). Similar framework was used in estimating aggregated productivity cost of DALYs lost in 2015 in Africa (World Health Organization Regional Office for Africa, 2019).

Kenya's total monetary value of DALYs (TMVDALY2017) lost from 166 diseases and injuries in 2017 was obtained through summation of the monetary value of DALY losses from each $i^{\text {th }}$ disease or injury (MVDALY $)$. This was expressed as follows:

$$
T M V D A L Y_{2017}=\sum_{i=1}^{n=166}\left(M V D A L Y_{1}+M V D A L Y_{2}+M V D A L Y_{3}+\cdots+M V D A L Y_{n}\right) \ldots
$$

where: $\sum_{1=}^{n=166}$ is the summation of monetary values of DALYs lost from the first to the onehundred-sixty-sixth disease (or injury); MVDALY ${ }_{1}$ is the monetary value of the first disease; MVDALY 2 is the monetary value of the second disease; $\operatorname{MVDALY}_{3}$ is the monetary value of the third disease; and $M V D A L Y_{n}$ is the monetary value of the $n^{\text {th }}$ disease.

The monetary value of each of the 166 diseases (or injuries) was obtained through multiplication of the net 2019 GDP for Kenya by the number of DALYs lost from each specific cause. That is:

$$
\begin{aligned}
& M V D A L Y_{1}=\left(N H G P C_{\text {Int } \$} \times D A L Y_{1}\right) \\
& M V D A L Y_{2}=\left(N H G P C_{\text {Int\$ }} \times D A L Y 2_{2}\right) \\
& M V D A L Y_{3}=\left(N H G P C_{\text {Int } \$} \times D A L Y_{3}\right) \ldots \\
& M V D A L Y_{n}=\left(N H G P C_{\text {Int } \$} \times D A L Y_{n}\right) .
\end{aligned}
$$

where: NHGPC ${ }^{\text {Int }}$ is the non-health GDP calculated by subtracting current health expenditure from the GDP per capita; MVDALY $1, \mathrm{MVDALY}_{2}, \mathrm{MVDALY}_{3}, \ldots, \mathrm{MVDALY}_{\mathrm{n}}$ are the monetary values of DALY lost from disease (or injury) 1, 2, 3 and $n$ (where $n=166^{\text {th }}$ disease or injury); $D A L Y_{1}$ is the number of DALYs lost from disease $1, D^{2} Y_{2}$ is the number of DALYs lost from disease $2, D^{2} Y_{3}$ is the number of DALYs lost from disease 3 , and DALY $n$ is the number of DALYs lost from $n^{\text {th }}$ disease.

\section{Estimation of the reductions in monetary value of DALY losses in Kenya assuming SDG3 related targets are achieved}

Box 1 below contains five targets for SDG3 which are used in estimating the envisaged reductions in monetary values of DALY losses in Kenya. 
BOX 1. Health SDG3 targets and expected percentage reductions for Kenya

\begin{tabular}{|c|c|c|}
\hline Target & Description & $\begin{array}{l}\text { Percentage } \\
\text { reduction } \\
\text { envisaged in SDG } \\
\text { targets }\end{array}$ \\
\hline SDG 3.1 & $\begin{array}{l}\text { By } 2030 \text {, reduce the global maternal mortality ratio to less } \\
\text { than } 70 \text { per } 100,000 \text { live births (WHO, 2019a; United Nations, } \\
\text { 2015). Average Annual Rate of Reduction (AARR) formula } \\
\text { (UNICEF, 2007). }\end{array}$ & $\begin{array}{l}86.27 \% \\
(A A R R=13.225 \%)\end{array}$ \\
\hline SDG 3.2 & $\begin{array}{l}\text { By } 2030 \text {, end preventable deaths of newborns, with all } \\
\text { countries aiming to reduce neonatal mortality to at least as } \\
\text { low as } 12 \text { per 1,000 live births (WHO, 2019a; United Nations, } \\
2015 \text { ). }\end{array}$ & $\begin{array}{l}42.857 \% \\
(\text { AARR }=3.9184 \%)\end{array}$ \\
\hline \multirow[t]{6}{*}{ SDG 3.3} & $\begin{array}{l}\text { By 2030, end the epidemics of AIDS, tuberculosis, malaria and } \\
\text { neglected tropical diseases and reduce hepatitis, water-borne } \\
\text { diseases and other communicable diseases (United Nations, } \\
\text { 2015). }\end{array}$ & \\
\hline & $\begin{array}{l}\text { (a). Reduce global HIV-related deaths from 1,062,352 in } 2015 \\
\text { to below } 500,000 \text { by } 2020 \text { (WHO, 2016a). }\end{array}$ & $\begin{array}{l}54.545 \% \\
\text { (AARR=5.4762\%) }\end{array}$ \\
\hline & $\begin{array}{l}\text { (b). Malaria mortality rates will be reduced globally by at least } \\
90 \% \text { from } 2015 \text { to } 2030 \text { (WHO, 2015a; WHO, 2017b). }\end{array}$ & $\begin{array}{l}90 \% \\
\text { (AARR=15.166\%) }\end{array}$ \\
\hline & $\begin{array}{l}\text { (c). The number of tuberculosis (TB) deaths will be reduced by } \\
90 \% \text { from } 2015 \text { to } 2030 \text { (WHO, 2017c; WHO, 2015b. }\end{array}$ & $\begin{array}{l}90 \% \\
\text { (AARR=15.166\%) }\end{array}$ \\
\hline & $\begin{array}{l}\text { (d).Mortality due to vector-borne diseases will be reduced } \\
\text { globally by at least } 75 \% \text { from } 2016 \text { to } 2030 \text { (Global Burden of } \\
\text { Disease Collaborative Network, 2017; WHO, 2017d). }\end{array}$ & $\begin{array}{l}75 \% \\
(A A R R=9.428 \%)\end{array}$ \\
\hline & $\begin{array}{l}\text { (e).Globally reduce viral hepatitis B and C deaths from } 1.4 \\
\text { million deaths reduced to less than 500,000 by } 2030 \text { (WHO, } \\
\text { 2016b). }\end{array}$ & \\
\hline SDG 3.4 & $\begin{array}{l}\text { By 2030, reduce premature mortality due to NCDs by one third } \\
\text { through prevention and treatment and promote mental health } \\
\text { and well-being (Global Burden of Disease Collaborative } \\
\text { Network, 2017; United Nations, 2015). }\end{array}$ & $\begin{array}{l}33.3 \% \\
(\text { AARR=2.855\%) }\end{array}$ \\
\hline SDG 3.6 & $\begin{array}{l}\text { By } 2020 \text {, halve the number of global deaths and injuries from } \\
\text { road traffic accidents (WHO, 2019a; United Nations, 2015; } \\
\text { Global Burden of Disease Collaborative Network, 2017). }\end{array}$ & $\begin{array}{l}50 \% \\
\text { (AARR=7.0905\% }\end{array}$ \\
\hline
\end{tabular}

The reductions in monetary values of DALYs lost, assuming the SDG targets for maternal mortality ratio (Target 3.1); neonatal mortality (Target 3.2); HIV/AIDS, tuberculosis, malaria, neglected tropical diseases (NTDs) and viral hepatitis deaths (target 3.3) are attained were estimated using equations (6) to (13).

(a). SDG 3 target 3.1: reduce the monetary value of DALYs from maternal disorders

$$
M V D A L Y_{M D 2030}=M V D A L Y_{M D 2017}-\left[M V D A L Y_{M D 2017} \times\left(\frac{M D D_{2017}-M D D_{T 3.1}}{M D D_{2017}}\right)\right] \ldots
$$

where: MVDALY ${ }_{M D 2030}$ is the monetary value of DALYs lost from maternal disorders in 2030; MVDALY $_{M D 2017}$ is the monetary value of DALYs lost from maternal disorders in 2017; $M D_{2017}$ are the 
maternal deaths in 2017; T3.1 is the SDG3 target 3.1 on maternal deaths; and $\mathrm{MDD}_{\mathrm{T} 3.1}$ are the maternal deaths in 2030 assuming target 3.1 is achieved. For example:

$$
M V D A L Y_{M D 2030}=\operatorname{Int} \$ 919,956,631-\left[\operatorname{Int} \$ 919,956,631 \times\left(\frac{510-70}{510}\right)\right]=\operatorname{Int} \$ 126,268,557 .
$$

(b). SDG 3 target 3.2: reduce the monetary value of DALYs from neonatal disorders

$$
M V D A L Y_{N D 2030}=M V D A L Y_{N D 2017}-\left[M V D A L Y_{N D 2017} \times\left(\frac{N D_{2017}-N D_{T 3.2}}{N D_{2017}}\right)\right] \ldots \text { (7) }
$$

where: MVDALY $_{\mathrm{ND2030}}$ is the monetary value of DALYs lost from neonatal disorders in 2030; MVDALY $_{\mathrm{ND2017}}$ is the monetary value of DALYs lost from neonatal disorders in 2017; $\mathrm{ND}_{2017}$ are the neonatal deaths in 2017; T3.2 is the SDG3 target 3.2 on neonatal deaths; $\mathrm{ND}_{\text {T3.2 }}$ are the neonatal deaths in 2030 assuming target 3.2 is achieved.

(c). SDG 3 target 3.3a: reduce the monetary value of DALYs from HIV

$$
M V D A L Y_{H I V D 2030}=M V D A L Y_{H I V D 2017}-\left[M V D A L Y_{H I V D 2017} \times\left(\frac{H I V D_{2017}-H I V D_{T 3.3 a}}{H I V D_{2017}}\right)\right] \ldots
$$

where: MVDALY HIVD2030 is the monetary value of DALYs lost from HIV/AIDS in 2030; MVDALY $_{\text {HIVD2017 }}$ is the monetary value of DALYs lost from HIV/AIDS in 2017; HIVD 2017 are the HIV/AIDS deaths in 2017; T3.3a is the SDG3 target 3.3a on HIV deaths; and HIVD T3.2 are the HIV/AIDS deaths in 2030 if target 3.3a is achieved.

(d). SDG 3 target 3.3b: reduce the monetary value of DALYs from malaria

$$
M V D A L Y_{M A D 2030}=M V D A L Y_{M A D 2017}-\left[M V D A L Y_{M A D 2017} \times\left(\frac{M A D_{2017}-M A D_{T 3.3 b}}{M A D_{2017}}\right)\right] \ldots
$$

where: MVDALY MAD2030 $_{\text {is }}$ the monetary value of DALYs lost from malaria in 2030; MVDALY MAD2017 $_{\text {is }}$ the monetary value of DALYs lost from malaria deaths in 2017; $M{ }_{2017}$ are the malaria deaths in 2017; T3.3b is the SDG3 target 3.3b on malaria deaths; and MAD ${ }_{\text {T3.3b }}$ are the malaria deaths in 2030 if target $3.3 \mathrm{~b}$ is achieved.

(e). SDG 3 target 3.3c: reduce the monetary value of DALYs from tuberculosis (TB)

$$
M V D A L Y_{T B D 2030}=M V D A L Y_{T B D 2017}-\left[M V D A L Y_{T B D 2017} \times\left(\frac{T B D_{2017}-T B D_{T 3.3 C}}{T B D_{2017}}\right)\right] \ldots
$$

where: MVDALY $\mathrm{TBD2030}_{\text {is }}$ is the monetary value of DALYs lost from TB in 2030; MVDALY $_{\text {TBD2017 }}$ is the monetary value of DALYs lost from TB in 2017; $\mathrm{TBD}_{2017}$ is the TB deaths in 2017; T3.3c is the SDG3 target $3.3 \mathrm{c}$ on TB deaths; and $\mathrm{TBD}_{\text {Tз.3с }}$ are the TB deaths in 2030 assuming target $3.3 \mathrm{c}$ is achieved.

(f). SDG 3 target 3.3d: reduce the monetary value of DALYs from neglected tropical disease (NTD)

$$
M V D A L Y_{N T D 2030}=M V D A L Y_{N T D 2017}-\left[M V D A L Y_{N T D 2017} \times\left(\frac{N T D_{2017}-N T D_{T 3.3 d}}{N T D_{2017}}\right)\right] \ldots
$$

where: MVDALY ${ }_{\text {NTD2030 }}$ is the monetary value of DALYs lost from NTD in 2030; MVDALY $_{\text {NTD2017 }}$ is the monetary value of DALYs lost from NTD deaths in 2017; NTD 2017 are the NTD deaths in 2017; T3.3d is the SDG3 target 3.3d on NTD deaths; and NTD ${ }_{\text {T3.3d }}$ are the NTD deaths in 2030 if target 3.3d is achieved.

(g). SDG 3 target 3.3e: reduce the monetary value of DALYs from viral hepatitis (VH) 


$$
M V D A L Y_{V H D 2030}=M V D A L Y_{V H D 2017}-\left[M V D A L Y_{V H D 2017} \times\left(\frac{V H D_{2017}-V H D_{T 3.3 e}}{V H D_{2017}}\right)\right] \ldots
$$

where: MVDALY $\mathrm{VHD}_{\mathrm{V} 030}$ is the monetary value of DALYs lost from viral hepatitis (VH) in 2030; MVDALY ${ }_{\mathrm{VHD} 2017}$ is the monetary value of DALYs lost from VH in 2017; $\mathrm{VHD}_{2017}$ are the VH deaths in 2017; T3.3e is the SDG3 target 3.3e on VH deaths; and VHD ${ }_{\text {T3.3e }}$ are the $\mathrm{VH}$ deaths in 2030 if target 3.3e is achieved.

(h). SDG 3 target 3.4: reduce the monetary value of DALYs from NCD

$$
M V D A L Y_{N C D 2030}=M V D A L Y_{N C D 2017}-\left[M V D A L Y_{N C D 2017} \times\left(\frac{N C D_{2017}-N C D_{T 3.4}}{N C D_{2017}}\right)\right] \ldots
$$

where: MVDALY NCD2030 $_{\text {is }}$ the monetary value of DALYs lost from NCD in 2030; MVDALY NCD2017 $_{\text {is }}$ the monetary value of DALYs lost from NCD in 2017; VHD 2017 are the NCD deaths in 2017; T3.4 is the SDG3 target 3.4 on NCD deaths; and NCD 3.4 are the NCD deaths in 2030 if target 3.4 is achieved.

(i). SDG 3 target 3.6: reduce the monetary value of DALYs from transport injury

$$
M V D A L Y_{I J D 2030}=\operatorname{MVDALY} Y_{I J D 2017}-\left[M V D A L Y_{I J D 2017} \times\left(\frac{I J D_{2017}-I J D_{T 3.6}}{I J D_{2017}}\right)\right] \ldots \ldots
$$

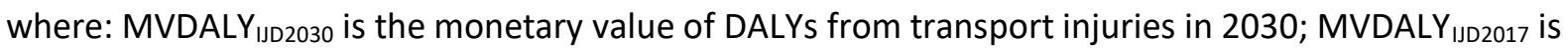
the monetary value of DALYs from transport injuries in 2017; $J_{2017}$ are the transport injuries deaths in 2017; T3.6 is the SDG3 target 3.6 on transport injury deaths; and IJD $D_{\mathrm{T} 3.6}$ are the transport injuries deaths in 2030 if target 3.6 is achieved.

\section{Estimation of potential savings in monetary value of DALY losses averted by 2030}

The potential reduction (savings) in monetary value of DALYs following full attainment of the five SDG3 targets was calculated as difference between the monetary value of DALYs lost in 2017 from i $^{\text {th }}$ cause and the monetary value of DALYs likely to be lost in 2030 from the same cause. For example, the potential reduction/savings in monetary value of DALYs lost from maternal disorders was:

$$
\begin{gathered}
M V D A L Y_{M D-S A V I N G S}=\left(M V D A L Y_{M D 2017}-M V D A L Y_{M D 2030}\right) \ldots(14) \\
M V D A L Y_{M D-S A V I N G S}=(\operatorname{Int} \$ 919,956,631-\operatorname{Int} \$ 126,268,557)=\operatorname{Int} \$ 793,688,074 .
\end{gathered}
$$

where: MVDALY MD-SAVINGS $_{\text {are }}$ the envisaged savings in monetary value of DALYs lost from maternal disorders; MVDALY ${ }_{M D 2030}$ is the monetary value of DALYs lost from maternal disorders in 2030; and MVDALY $_{\mathrm{MD} 2017}$ is the monetary value of DALYs lost from maternal disorders in 2017.

\section{Data Sources and Software}

The DALYs data for the 166 causes were from IHME (Global Burden of Disease Collaborative Network, 2018), GDP per capita data from the International Monetary Fund world economic outlook database (International Monetary Fund, 2019), and the current health expenditure per person data from the WHO Global Health Expenditure Database (World Health Organization, 2019b). The fourteen equations shown above were calculated with Excel Software developed by Microsoft (New York). 


\section{Results}

\section{Estimates of monetary value of DALYs Lost in Kenya in 2017}

All diseases: Kenya incurred a total loss of 17,856,955 DALYs among people of all ages in 2017 (Global Burden of Disease Collaborative Network, 2017). Those DALYs lost had a total monetary value of Int\$ $67,012,790,388$; and an average value of Int $\$ 3,753$ per DALY lost. Approximately, 56.64\% of monetary value of DALYs lost emanated from communicable, maternal, neonatal, and nutritional diseases; $35.94 \%$ from non-communicable diseases; and $7.42 \%$ from injuries.

Figure 2 displays distribution of the monetary value of DALYs lost from all causes by age groups.

"[insert Figure 2.]"

The people aged 14 years and below incurred DALYs valued at Int $\$ 25,964,877,620$ (38.7\%); 15-59 years olds suffered DALY loss valued at Int\$32,888,431,641 (49.1\%); and those aged 60 years and above borne DALY loss worth Int\$ 8,159,481,127 (12.2\%).

\section{Communicable, maternal, neonatal, and nutritional diseases}

Figure 3 depicts shows that a total of DALYs worth Int $\$ 37,952,637,789$ was lost from communicable, maternal, neonatal, and nutritional diseases.

\section{"[insert Figure 3.]"}

About 28.6\% of MVDALY from CMNN was caused by HIV/AIDS and sexually transmitted infections; 19.8\% maternal and neonatal Infections; $19.0 \%$ was from respiratory infections and tuberculosis; $15.5 \%$ from enteric infections; $8.2 \%$ other infectious diseases; $4.9 \%$ nutritional disorders; and $4.1 \%$ from neglected tropical diseases and malaria.

HIV/AIDS and sexually transmitted infections: The DALYs lost due to HIV/AIDS and sexually transmitted infections (STI) were valued at Int\$ 10.84 billion. HIV/AIDS accounted for $96.6 \%$ and STI for $3.4 \%$ of that monetary value.

Respiratory infections \& tuberculosis: Respiratory infections and tuberculosis (TB) led to a DALY loss valued Int $\$ 7.203$ billion. Lower respiratory infections, TB, upper respiratory infections and otitis media accounted for $63.9 \%, 32.3 \%, 2.9 \%$ and $0.9 \%$ of the monetary value, respectively.

Enteric infections: The enteric infections caused a DALY loss with a monetary value of Int\$ 5.88 billion. Of that monetary value, diarrhoeal diseases accounted for $82.7 \%$, invasive non-typhoidal Salmonella for $11.3 \%$, typhoid and paratyphoid for $5.9 \%$, and other intestinal infectious diseases for $0.1 \%$.

Neglected Tropical Diseases (NTDs) \& Malaria: Malaria and NTDs led to a DALY loss valued Int\$ 1.54 billion; with malaria accounting for Int\$1.092 billion (70.9\%) and NTDs for Int\$0.447 billion (29.1\%). Table 1 shows the distribution of monetary value of DALYs lost from individual NTDs.

Table 1: Monetary value of DALYs lost from NTDs (in 2019 Int\$)

\begin{tabular}{|l|l|r|}
\hline NTD & $\begin{array}{l}\text { Monetary value } \\
\text { in Int\$ }\end{array}$ & Percent \\
\hline Schistosomiasis & $220,314,394$ & 49.27 \\
\hline Intestinal nematode infections & $55,333,984$ & 12.38 \\
\hline Leishmaniasis & $44,498,104$ & 9.95 \\
\hline Cysticercosis & $35,821,824$ & 8.01 \\
\hline
\end{tabular}




\begin{tabular}{|l|l|r|} 
Rabies & $25,760,440$ & 5.76 \\
\hline Dengue & $14,136,229$ & 3.16 \\
\hline Yellow fever & $12,394,580$ & 2.77 \\
\hline Trachoma & $3,781,714$ & 0.85 \\
\hline Lymphatic filariasis & $2,320,028$ & 0.52 \\
\hline Cystic echinococcosis & 559,598 & 0.13 \\
\hline Leprosy & 197,041 & 0.04 \\
\hline Other neglected tropical diseases & $32,032,296$ & 7.16 \\
\hline TOTAL & $\mathbf{4 4 7 , 1 5 0 , 2 3 2}$ & $\mathbf{1 0 0 . 0 0}$ \\
\hline
\end{tabular}

Schistosomiasis, intestinal nematode infections and leishmaniasis alone accounted for $71.6 \%$ of total monetary value of DALYs lost from NTDs.

Other Infectious Diseases: Table 2 portrays that the monetary value of DALYs lost from other infectious diseases was Int 3.11 billion. Meningitis, tetanus and whooping cough accounted for $73.5 \%$ of that monetary value.

Table 2: Monetary value of DALYs lost from other infectious diseases

\begin{tabular}{|l|l|r|}
\hline Diseases & $\begin{array}{l}\text { Monetary value } \\
\text { in Int\$ }\end{array}$ & \multicolumn{2}{|l|}{ Percent } \\
\hline Meningitis & $1,283,117,273$ & 41.3 \\
\hline Tetanus & $626,152,366$ & 20.1 \\
\hline Whooping cough & $377,191,575$ & 12.1 \\
\hline Measles & $245,273,599$ & 7.9 \\
\hline Acute hepatitis & $178,030,859$ & 5.7 \\
\hline Encephalitis & $123,291,717$ & 4 \\
\hline Varicella and herpes zoster & $39,493,471$ & 1.3 \\
\hline Diphtheria & $3,092,609$ & 0.1 \\
\hline Other unspecified infectious diseases & $232,625,052$ & 7.5 \\
\hline TOTAL & $3,108,268,522$ & 100 \\
\hline
\end{tabular}

Maternal and neonatal infections: Maternal and neonatal infections led to a DALY loss valued at Int\$ 7.51 billion. Neonatal disorders accounted for $87.7 \%$ and maternal disorders for $12.3 \%$ of the monetary value.

Nutritional disorders: Nutrition disorders caused DALY losses valued at Int $\$ 1.88$ billion. That monetary value was attributed to protein-energy malnutrition (52.6\%), dietary iron deficiency (25.5\%), vitamin A deficiency (18.8\%), iodine deficiency (1.9\%), and other nutritional deficiencies (1.2\%).

\section{Non-communicable diseases}

Neoplasms (cancers): Figure 4 shows the monetary value of DALYs lost from neoplasms (cancer) in Kenya estimated at Int $2,596,076,616$, i.e. $3.9 \%$ of national monetary value of DALYs. About $61.2 \%$ was from ten types of cancer, including breast cancer (8.7\%), cervical cancer (7.7\%), stomach cancer (7.7\%), oesophageal cancer (6.3\%), colon and rectum cancer (6.2\%), leukaemia (5.9\%), liver cancer (5.5\%), non-Hodgkin lymphoma (4.8\%), prostate cancer (4.2\%), and tracheal, bronchus, and lung cancer (4.2\%). 


\section{"[insert Figure 4.]"}

Cardiovascular diseases: Figure 5 portray that cardiovascular diseases resulted in a DALY loss valued at Int\$3,567,563,123 (5.3\% of national total). Approximately Int\$ 2.92 billion (81.8\%) stemmed from stroke, ischemic heart disease and hypertensive heart disease.

\section{"[insert Figure 5.]"}

Chronic respiratory diseases: The DALYs from chronic respiratory diseases were valued at Int $\$ 1.21$ billion (1.8\% of national total). That resulted from chronic obstructive pulmonary disease (54.3\%), asthma (37.4\%), interstitial lung disease and pulmonary sarcoidosis (1.9\%), pneumoconiosis $(0.4 \%)$ and other chronic respiratory diseases (5.9\%).

Digestive diseases: A shown in Figure 6, the DALYs lost from digestive diseases were valued at Int\$ $2,639,735,063$ (3.9\% of national total). Nearly $86.5 \%$ of the monetary value of DALYs was attributed to cirrhosis and other chronic liver diseases (48.1\%), upper digestive system diseases $(21.9 \%)$, and paralytic ileus and intestinal obstruction (16.5\%).

\section{"[insert Figure 6.]"}

Neurological Disorders: The DALYs from neurological disorders had a monetary value of 1.963 billion, which was $2.9 \%$ of the national total. That monetary value was attributed to headache disorders (46.4\%), epilepsy (34.3\%), Alzheimer's disease and other dementias (11.2\%), Parkinson's disease (2\%), multiple sclerosis $(0.3 \%)$, motor neuron disease $(0.04 \%)$ and Other neurological disorders $(5.8 \%)$.

Mental disorders: Figure 7 depicts that the mental disorders caused DALY losses valued at Int\$2.464 billion, which was $3.7 \%$ of the national total. Almost $67 \%$ of the monetary value was attributed to depressive disorders (33.1\%), anxiety disorders (23.6\%) and conduct disorder (10.3\%).

\section{"[insert Figure 7.]"}

Substance use disorders: Substance use disorders caused DALY losses valued at Int\$ 0.522 billion, which was $0.8 \%$ of the national total. Alcohol use disorders and drug use disorders accounted for $49.8 \%$ and $50.2 \%$ of the monetary value, respectively.

Diabetes and kidney diseases: Diabetes and kidney diseases led to DALY losses valued at Int\$1.76 billion, which was $2.6 \%$ of the national total. Diabetes mellitus, chronic kidney disease and acute glomerulonephritis accounted for $65.0 \%, 34.7 \%$ and $0.3 \%$, respectively.

Skin and Subcutaneous Diseases: Skin and subcutaneous diseases triggered DALY losses valued at Int\$ 1.14 billion, which was $1.7 \%$ of the national total (see Table 3 ). Approximately $76.7 \%$ of the monetary value resulted from dermatitis, urticarial, scabies, viral skin diseases and fungal skin diseases.

Table 3: Monetary value of DALYs lost from skin and subcutaneous diseases

\begin{tabular}{|l|l|r|}
\hline Diseases & $\begin{array}{l}\text { Monetary Value in } \\
\text { Int\$ }\end{array}$ & \multicolumn{1}{l|}{ Percent } \\
\hline Dermatitis & $401,709,848$ & 35.3 \\
\hline Urticaria & $140,065,174$ & 12.3 \\
\hline Scabies & $130,192,999$ & 11.4 \\
\hline Viral skin diseases & $118,794,374$ & 10.4 \\
\hline Fungal skin diseases & $82,598,671$ & 7.2 \\
\hline Bacterial skin diseases & $75,246,780$ & 6.6 \\
\hline Psoriasis & $66,695,632$ & 5.9 \\
\hline
\end{tabular}




\begin{tabular}{|l|l|r|} 
Acne vulgaris & $51,506,481$ & 4.5 \\
\hline Pruritus & $14,771,863$ & 1.3 \\
\hline Alopecia areata & $9,608,789$ & 0.8 \\
\hline Decubitus ulcer & $3,654,204$ & 0.3 \\
\hline Other skin and subcutaneous diseases & $44,563,683$ & 3.9 \\
\hline Sub-Total & $\mathbf{1 , 1 3 9 , 4 0 8 , 4 9 7}$ & 100.0 \\
\hline
\end{tabular}

Sense organ diseases: Sense organ disorders caused DALY losses valued at Int\$ 1.02 billion, which was $1.5 \%$ of national total. This monetary value was made up of blindness and vision impairment (43.5\%), age-related and other hearing loss (53.0\%), and other sense organ diseases (3.5\%).

Musculoskeletal disorders: Musculoskeletal disorders caused DALY losses valued at Int\$ 1.66 billion, which was $2.5 \%$ of the national total. That monetary value is made up of low back pain (63.6\%), neck pain $(18.1 \%)$, osteoarthritis $(4.2 \%)$, rheumatoid arthritis $(2.7 \%)$, gout $(0.8 \%)$ and other musculoskeletal disorders (10.6\%).

Other non-communicable diseases: The other non-communicable diseases shown in Table 4 caused DALY losses valued at Int\$ 3.553 billion, which was $5.3 \%$ of the national total. Congenital birth defects, gynaecological diseases, and urinary diseases and male infertility account for $79.9 \%$ of the monetary value.

Table 4: Monetary value of DALYs lost from other non-communicable diseases

\begin{tabular}{|l|l|r|}
\hline Other non-communicable diseases & $\begin{array}{l}\text { Monetary value of } \\
\text { DALY (Int\$) }\end{array}$ & Percent \\
\hline Congenital birth defects & $2,378,122,089$ & 66.9 \\
\hline Urinary diseases and male infertility & $246,569,745$ & 7 \\
\hline Gynaecological diseases & $214,670,749$ & 6 \\
\hline Hemoglobinopathies and hemolytic anemias & $242,382,934$ & 6.8 \\
\hline Endocrine, metabolic, blood, and immune disorders & $93,705,202$ & 2.6 \\
\hline Oral disorders & $240,215,738$ & 6.8 \\
\hline Sudden infant death syndrome & $137,102,388$ & 3.9 \\
\hline Sub-Total & $3,552,768,846$ & 100.0 \\
\hline
\end{tabular}

\section{Injuries}

All forms of injuries resulted in DALY losses valued at Int\$ 4,975,569,762 (see Figure 8).

\section{"[insert Figure 8.]"}

Out of the total monetary value of DALYs lost from injuries, unintentional injuries accounted for Int $\$ 2.08$ billion (42\%), self-harm and interpersonal violence for Int\$1.6 billion (32.2\%), and transport injuries for Int $\$ 1.3$ billion (25.8\%). Sixty-four percent of the monetary value from injuries was attributed to road injuries (23.0\%), interpersonal violence (19.3), falls (12.1\%) and self-harm (9.6\%).

\section{Monetary Value of DALYs Lost in 2017 from Five SDG 3 Related Targets}


In 2017 SDG-related health conditions and diseases caused a total of 12,627,303 DALY loss, which had a monetary value of Int $\$ 47,387,208,551$ (70.71\%). As indicated in Table 5, NCDs, HIV/AIDS and neonatal disorders accounted for $86.83 \%$ of the monetary value of SDG-related DALYs lost.

Table 5: Monetary value of DALYs lost in 2017 from five SDG 3 related targets (2019 Int\$)

\begin{tabular}{|l|l|l|r|}
\hline SDG3 Targets & $\begin{array}{l}\text { DALYs in } \\
\mathbf{2 0 1 7 ^ { * }}\end{array}$ & $\begin{array}{l}\text { Monetary value of } \\
\text { DALYs lost (Int\$ or } \\
\text { PPP) }\end{array}$ & Percent $^{* * *}$ \\
\hline SDG 3.1: Maternal disorders & 245,142 & $919,956,631$ & 1.94 \\
\hline SDG3.2: Neonatal disorders & $1,755,556$ & $6,588,173,277$ & 13.9 \\
\hline SDG3.3a: HIV Mortality & $2,790,267$ & $10,471,190,093$ & 22.1 \\
\hline SDG3.3b: Malaria mortality & 290,926 & $1,091,772,390$ & 2.3 \\
\hline SDG3.3c: TB deaths & 619,443 & $\mathbf{2 , 3 2 4 , 6 1 7 , 8 1 5}$ & 4.91 \\
\hline SDG3.3d: NTDs & 119,153 & $447,150,232$ & 0.94 \\
\hline SDG 3.3e: Acute hepatitis & 47,440 & $178,030,859$ & 0.38 \\
\hline SDG3.4: NCDs & $6,417,832$ & $\mathbf{2 4 , 0 8 4 , 5 8 2 , 8 3 7}$ & 50.83 \\
\hline SDG3.6: Traffic injuries & 341,544 & $1,281,734,417$ & 2.7 \\
\hline Total for SDG-related & $\mathbf{1 2 , 6 2 7 , 3 0 3}$ & $\mathbf{4 7 , 3 8 7 , 2 0 8 , 5 5 1}$ & $\mathbf{1 0 0}$ \\
\hline National Total & $\mathbf{1 7 , 8 5 6 , 9 5 5}$ & $\mathbf{6 7 , 0 1 2 , 7 9 0 , 3 8 8}$ & \\
\hline
\end{tabular}

Sources: *DALYs data from IHME database (Global Burden of Disease Collaborative Network, 2017).

${ }^{* *}$ Monetary value of DALYs lost (Int\$ or PPP) and ${ }^{* * *}$ Percent are authors estimates.

\section{Estimates of Reductions in Monetary Value of DALY Losses in Kenya if the Five SDG 3 Related Targets Are Achieved by 2030}

Table 6 presents the monetary value of DALYs lost in 2017, monetary value of DALYs lost in 2030 and envisaged monetary reductions distributed by SDG health conditions.

Table 6: Monetary value of DALYs lost distributed by SDG health conditions

\begin{tabular}{|l|l|l|l|}
\hline & $\begin{array}{l}\text { (A). Monetary Value } \\
\text { of DALYS lost in } \\
\mathbf{2 0 1 7} \text { (Int\$) }\end{array}$ & $\begin{array}{l}\text { (B). Monetary } \\
\text { Value of DALYS } \\
\text { lost in 2030 (Int\$) }\end{array}$ & $\begin{array}{l}\text { (C). Reduction in } \\
\text { Monetary Value of } \\
\text { DALYS lost in 2030 } \\
\text { (Int\$) [C=A-B)] }\end{array}$ \\
\hline SDG 3.1: Maternal disorders & $\mathbf{9 1 9 , 9 5 6 , 6 3 1}$ & $\mathbf{1 2 6 , 2 6 8 , 5 5 7}$ & $\mathbf{7 9 3 , 6 8 8 , 0 7 4}$ \\
\hline SDG 3.2: Neonatal disorders & $\mathbf{6 , 5 8 8 , 1 7 3 , 2 7 7}$ & $\mathbf{3 , 7 6 4 , 6 7 0 , 4 4 4}$ & $\mathbf{2 , 8 2 3 , 5 0 2 , 8 3 3}$ \\
\hline SDG 3.3: Tuberculosis & $\mathbf{2 , 3 2 4 , 6 1 7 , 8 1 5}$ & $\mathbf{2 3 2 , 4 6 1 , 7 8 1}$ & $\mathbf{2 , 0 9 2 , 1 5 6 , 0 3 3}$ \\
\hline SDG 3.3: HIV/AIDS & $\mathbf{1 0 , 4 7 1 , 1 9 0 , 0 9 3}$ & $\mathbf{4 , 7 5 9 , 6 3 1 , 8 6 1}$ & $\mathbf{5 , 7 1 1 , 5 5 8 , 2 3 3}$ \\
\hline SDG 3.3: Malaria & $\mathbf{1 , 0 9 1 , 7 7 2 , 3 9 0}$ & $\mathbf{1 0 9 , 1 7 7 , 2 3 9}$ & $\mathbf{9 8 2 , 5 9 5 , 1 5 1}$ \\
\hline SDG 3.3: Acute hepatitis & $\mathbf{1 7 8 , 0 3 0 , 8 5 9}$ & $\mathbf{6 3 , 5 8 2 , 4 4 9}$ & $\mathbf{1 1 4 , 4 4 8 , 4 0 9}$ \\
\hline SDG 3.3: NTDs (a+b..+l) & $\mathbf{4 4 7 , 1 5 0 , 2 3 2}$ & $\mathbf{1 1 1 , 7 8 7 , 5 5 8}$ & $\mathbf{3 3 5 , 3 6 2 , 6 7 4}$ \\
\hline (a). Schistosomiasis & $\mathbf{2 2 0 , 3 1 4 , 3 9 4}$ & $55,078,598$ & $165,235,795$ \\
\hline $\begin{array}{l}\text { (b). Intestinal nematode } \\
\text { infections }\end{array}$ & $55,333,984$ & $13,833,496$ & $41,500,488$ \\
\hline (c). Leishmaniasis & $44,498,104$ & $11,124,526$ & $33,373,578$ \\
\hline (d). Cysticercosis & $35,821,824$ & $8,955,456$ & $26,866,368$ \\
\hline (e). Rabies & $25,760,440$ & $6,440,110$ & $19,320,330$ \\
\hline
\end{tabular}




\begin{tabular}{|c|c|c|c|}
\hline (f). Dengue & $14,136,229$ & $3,534,057$ & $10,602,172$ \\
\hline (g).Yellow fever & $12,394,580$ & $3,098,645$ & $9,295,935$ \\
\hline (h).Trachoma & $3,781,714$ & 945,429 & $2,836,286$ \\
\hline (i).Lymphatic filariasis & $2,320,028$ & 580,007 & $1,740,021$ \\
\hline (j).Cystic echinococcosis & 559,598 & 139,899 & 419,698 \\
\hline (k).Leprosy & 197,041 & 49,260 & 147,781 \\
\hline $\begin{array}{l}\text { (I).Other neglected tropical } \\
\text { diseases }\end{array}$ & $32,032,296$ & $8,008,074$ & $24,024,222$ \\
\hline $\begin{array}{l}\text { SDG 3.4: Non-communicable } \\
\text { diseases }(a+b+c+. .+1)\end{array}$ & $24,084,582,837$ & $16,056,468,840$ & $8,028,113,997$ \\
\hline (a). Neoplasms & $2,596,076,616$ & $1,730,726,397$ & $865,350,218$ \\
\hline (b). Cardiovascular Diseases & $3,567,563,123$ & $2,378,387,307$ & $1,189,175,816$ \\
\hline $\begin{array}{l}\text { (c) Chronic respiratory } \\
\text { diseases }\end{array}$ & $1,205,075,880$ & $803,387,937$ & $401,687,943$ \\
\hline (d). Digestive diseases & $2,639,735,063$ & $1,759,832,175$ & $879,902,889$ \\
\hline (e).Neurological Disorders & $1,962,721,321$ & $1,308,487,423$ & $654,233,898$ \\
\hline (f). Mental Disorders & $2,463,518,824$ & $1,642,354,095$ & $821,164,730$ \\
\hline (g). Substance Use Disorders & $521,794,946$ & $347,865,036$ & $173,929,909$ \\
\hline $\begin{array}{l}\text { (h). Diabetes and Kidney } \\
\text { Diseases }\end{array}$ & $1,759,422,548$ & $1,172,954,230$ & $586,468,318$ \\
\hline $\begin{array}{l}\text { (i). Skin and Subcutaneous } \\
\text { Diseases }\end{array}$ & $1,139,408,497$ & $759,609,463$ & $379,799,034$ \\
\hline (j). Sense Organ Diseases & $1,020,302,380$ & $680,204,988$ & $340,097,392$ \\
\hline (k). Musculoskeletal Disorders & $1,656,194,793$ & $1,104,135,383$ & $552,059,410$ \\
\hline $\begin{array}{l}\text { (I).Other non-communicable } \\
\text { diseases }\end{array}$ & $3,552,768,846$ & $2,368,524,406$ & $1,184,244,439$ \\
\hline SDG 3.6: Transport injuries & $1,281,734,417$ & $640,867,208$ & $640,867,208$ \\
\hline TOTAL (INT\$) & $47,387,208,550$ & $25,864,915,938$ & $21,522,292,613$ \\
\hline
\end{tabular}

We estimate that full attainment of the five SDG 3 targets would lead to a $45.42 \%$ decrease in the monetary value of DALYs lost by 2030.

\section{Discussion}

\section{Key findings}

The 17,856,955 DALYs lost among people of all ages in 2017 had a total monetary value of Int\$ $67,012,790,388$. Of which, $56.64 \%$ was attributed to communicable, maternal, neonatal, and nutritional diseases; $35.94 \%$ to non-communicable diseases; and $7.42 \%$ to injuries. Close to half of the monetary value of DALYs lost was incurred by the 15-59 years old. We estimate that full attainment of the five SDG 3 targets would lead to a Int\$ 21.52 billion (45.42\%) decrease in the monetary value of DALYs lost by 2030.

\section{SDG 3.1 and SDG 3.2: Maternal and neonatal disorders}

Were Kenya to fully attain SDG targets 3.1 and 3.2 by 2030 , the country would annually prevent loss of DALYs with a monetary value of Int $793,688,074$. That kind of saving might be achieved if the both the national road map for accelerating the attainment of the MDGs related to maternal and newborn health (Republic of Kenya, 2010a); and the reproductive, maternal, newborn, child and adolescent 
health (RMNCAH) investment framework (Republic of Kenya, 2016a) are fully implemented in all the 47 Administrative Counties. The latter document was informed by the global strategy for women's, children's and adolescents' health (2016-2030) (Every Woman Every Child, 2015), the UN General Assembly (UNGA) resolution on the girl child (UN, 2017a), the UNGA resolution on the right to food (UN, 2017b), and the World Health Assembly resolution on immunization (WHO, 2017e).

\section{SDG 3.3: Tuberculosis, HIV/AIDS, Malaria, Acute hepatitis and NTDs}

The realization of SDG target 3.3 by 2030 would annually save Kenya DALYs with a monetary value of Int\$2,092,156,033 from TB, Int\$5,711,558,233 from HIV/AIDS, Int\$982,595,151 from malaria, Int\$ $114,448,409$ from Acute Hepatitis and Int $\$ 335,362,674$ from NTDS. In other words, the country stands to save DALYs worth Int\$7.144 billion.

The saving could be made through full implementation the Kenya's AIDS strategic framework 2014/2015 - 2018/2019 (Republic of Kenya, 2014a); national strategic plan for tuberculosis, leprosy and lung health 2019-2023 (Republic of Kenya, 2018a); HIV and AIDS/STI and TB multisectoral strategic plan and implementation framework 2015 - 2020 (East African Community, 2015); malaria strategy 2019-2023 (Republic of Kenya, 2018b); malaria communication strategy 2016-21 (Ministry of Health, 2016); guidelines for the treatment of chronic hepatitis $B$ and $C$ viral infections (Ministry of Health, 2014a); national strategic plan for control of neglected tropical diseases 2016-2020 (Republic of Kenya, 2015a); and national health promotion strategy (Ministry of Health, 2012).

The implementation of communicable diseases strategies and plans is buttressed with pertinent legal framework, including the Health Act (Republic of Kenya, 2017a); Public Health Act (Republic of Kenya, 2012a); HIV and AIDS prevention and control Act (Republic of Kenya, 2012b); the sexual offences Act (Republic of Kenya, 2012c); and the malaria prevention Act (Republic of Kenya, 2012d).

At the global level, United Nations General Assembly (UNGA) declared political commitment for the fight against HIV/AIDS (UN, 2016a), malaria (UN, 2018a), TB (UN, 2018b), and NTDs (WHO, 2017f; UN, 2017c).

\section{SDG 3.4: Non-communicable diseases}

Should Kenya fully reduce by one third epidemiological burden from NCDs by 2030 (SDG3 target 3.4), it would save DALYs valued at Int\$ Int\$ 8,028,113,997. Such a saving might be realized via full implementation of the national health policies, strategic plans and guidelines. For instance, the Kenya national health policy 2014-2030 (Republic of Kenya, 2014b; the Kenya health sector strategic and investment plan (KHSSIP) (Republic of Kenya, 2014c); the national strategy for the prevention and control of NCD 2015 - 2020 (Republic of Kenya, 2015b); the national nutrition action plan 2012-2017 (Republic of Kenya, 2012e); mental health policy 2015-2030 (Republic of Kenya, 2016b); the national cancer control strategy 2017 - 2022 (Republic of Kenya, 2017b); the national cancer screening guidelines (Republic of Kenya, 2018c); the national guidelines for cardiovascular diseases management (Republic of Kenya, 2018d); the national diabetes strategy 2010-2015 (Republic of Kenya, 2010b); the national physical activity action plan (Republic of Kenya, 2018e); and the national guidelines for healthy diets and physical activity (Republic of Kenya, 2017c) provide pertinent guidance for attenuating the disease burden from NCDs.

The development of Kenyan policies and strategic documents were partially informed by the World Health Assembly (WHA) resolutions on physical activity (WHO, 2018a); infant and child feeding (WHO, 2018b); rheumatic fever and rheumatic heart disease (WHO, 2018c); cancer prevention and control 
(2017g); global strategy for the prevention and control of NCD (WHO, 2000); and action plan for the prevention and control of NCDs (WHO, 2013).

The implementation of NCD strategies and plans is strongly anchored in various legal instruments, such as, the Kenya Constitution (Republic of Kenya, 2010c); the cancer prevention and control Act (Republic of Kenya, 2012f); the tobacco control Act (Republic of Kenya, 2012g); and the Alcoholic Drinks Control Act (Republic of Kenya, 2012h).

At the global level, in 2018 and 2012, the United Nations General Assembly committed to provide strategic high-level leadership through whole-of-government and health-in-all-policies approaches for scale-up of the prevention and control of NCDs (UN, 2018c; UN, 2012).

\section{SDG 3.6: Transport injuries}

Incase Kenya succeeded in reducing by half the epidemiological burden from road accidence, it would reduce DALYs with a monetary value of Int $\$ 640,867,208$. With a view to stemming the tide of deaths and injuries associated with transport injuries, the country developed a policy, strategy and action plan for road safety (Republic of Kenya, 2009; Republic of Kenya, 2015c) and the violence and injury prevention and control action plan 2018-2022 (Republic of Kenya, 2018f) consisting of the following five components:

a) Road safety management: including road safety coordination and management, mainstreaming, funding, data systems, research, and monitoring and evaluation.

b) Safer road and mobility: encompassing development and maintenance of safer road, and the vulnerable road users.

c) Safer vehicles: covering vehicle safety standards and compliance, and public transport regulations.

d) Safer road users: incorporating driver training, testing and licensing; road safety legislations and regulations; traffic law enforcement; road safety awareness/ public education; and road safety, children and education.

e) Post-crash care: availability and accessibility to emergency services and rehabilitation.

Kenya's national transport and safety authority Act No. 33 of 2012 provides the legal framework for implementation of the above mentioned policy, strategy and plan (Republic of Kenya, 2014d).

Kenya's road safety policy framework is underpinned by the UNGA resolution A/RES/64/255 that proclaims the period 2011-2020 as the Decade of Action for Road Safety (UN, 2010). The UNGA resolutions A/RES/72/271 (UN, 2018d) and A/RES/70/260 (UN, 2016b) both entitled "improving global road safety" provides further political support for sustained implementation of strategies for curbing transport related deaths and non-fatal injuries of people.

\section{Limitations of the study}

The study reported in this paper has limitations related to accuracy of mortality and disability data upon which DALY estimations are based; weaknesses of the GDP calculations; and shortcomings of the human capital approach.

Firstly, in Kenya civil registration of births and deaths is a National Government function based in the Ministry of Interior and Coordination of National government. The process hinges on a communitybased system of civil registration, where Assistant Chiefs (Local government administrators) record in register books births and deaths occurring at home, while health workers record those occurring at health facility (Republic of Kenya, 2012i). In some cases, due to ignorance of Government's 
requirement, parents might not report births and deaths that occur at home. And even when parents (or next of kin) report deaths occurring at home, the cause of death might be wrong, since often there are no inquiries as to cause of death. For these reasons, the mortality statistics upon which YLL calculations are based might not be accurate. According to WHO (WHO, 2019a) completeness of cause of death data in the WHO African region was about 6\% between 2009-2017 due to weak civil registration systems in countries. The GBD 2017 Mortality Collaborators (GBD 2017 Mortality Collaborators, 2018) and GBD 2017 Cause of Death Collaborators (GBD 2017 Cause of Death Collaborators, 2018) discuss limitations related to accuracy of the mortality and causes of death data used the Global Burden of Disease Study 2017 study. The GBD 2017 Disease and Injury Incidence and Prevalence Collaborators (GBD 2017 Disease and Injury Incidence and Prevalence Collaborators, 2018) expounds on the shortcomings of the national data used in estimating YLD for various diseases and injuries. Therefore, as explained clearly by the GBD 2017 DALYs and HALE Collaborators, DALY estimates are influenced by availability and quality of data for YLL and YLD (GBD 2017 DALYs and HALE Collaborators, 2018).

Second, GDP as a measure of wellbeing of societies has weaknesses, such as, ignoring economic, social, political and ecological inequalities and their ramifications (Stiglitz, Sen \& Fitttousi, 2009); does not factor-in quality of life, happiness and wellbeing; disregards negative environmental consequences of economic production processes (Giannetti, Agostinho, Almeida \& Huisingh, 2015); and omits non-marketed services (Freimann, 2016), e.g. contribution of homemakers, including cooking, cleaning, washing, fetching water, hewing firewood, cultivating, inculcating societal values, childcare, caring for the elderly, nursing the sick at home, etc.

Finally, unlike the willingness-to-pay/willingness-to-accept approach proffered by some economists, the HCA does not take into account strength of individual preferences to either avert (or accept) the risk of incurring a DALY loss (Jones-Lee, 1985; Mishan, 1971); and strictly applied HCA would value DALY losses occurring among anyone below the minimum working age and past retirement age at zero (Jones-Lee, 1985).

In order to avoid discriminating against people below the working age, the homemakers, the unemployed and the retired, the current study did not adjust the net GDP per capita for those factors. Thus, every DALY was valued at the same net GDP per capita, irrespective of the age and employment status.

\section{Conclusions}

In 2017 the DALYs lost in Kenya had a monetary value equivalent to $34.8 \%$ of the national 2019 GDP. Full attainment of the disease and injuries related SDG 3 targets would lead to a $45.42 \%$ decrease in the monetary value of SDG3 targets-related DALYs lost by 2030. There exist national health-related legislations, policies, strategies and plans which if fully funded and implemented would enable Kenya to strengthen its health system and health programmes, and consequently, assure universal health coverage of essential health services related to SDG3 targets.

Therefore, there is urgent need for health policy-makers to use the kind of evidence reported in this paper to advocate among public and private sectors for increased spending on health development to the levels recommended by Stenberg et al., 2017. 


\section{Acknowledgements}

R.N.D.K.M. is very grateful for support and encouragement of her PhD thesis supervisors (Dr Joyce Shirinde and Dr Flavia Senkubuge) at the School of Health Systems and Public Health, University of Pretoria, Pretoria, South Africa. We owe profound gratitude to Jehovah Jireh for meeting all our needs in the entire process of the study reported in this paper.

\section{Author Contributions}

R.N.D.K.M. and J.M.K. designed the study; reviewed pertinent literature; collated data from IHME, IMF and WHO databases; analysed data and wrote the paper. Both authors read and approved the final manuscript.

\section{Funding acknowledgements}

This research received no specific grant from any funding agency in the public, commercial, or notfor-profit sectors.

\section{Declaration of Conflicting of Interest}

The Authors declares that there is no conflict of interest.

\section{Ethics Approval and Consent to Participate}

This study did not involve the use of animal or human data or products. The analysis was based solely on secondary statistical data published in the IHME, IMF and WHO databases. Therefore, ethical approval and consent to participate was not applicable for the study reported in this manuscript.

\section{ORCID iD}

Joses Muthuri Kirigia - https://orcid.org/0000-0002-2317-4666

Rose Nabi Deborah Karimi Muthuri - https://orcid.org/0000-0003-0353-8132

\section{Availability of Data and Materials}

The secondary data analysed during the current study is publicly available from the following websites:

- DALY data from IHME database: http://ghdx.healthdata.org/gbd-results-tool

- GDP data from IMF database: https://www.imf.org/external/pubs/ft/weo/2018/02/weodata/index.aspx

- Per capita current health expenditure data from WHO Database: http://apps.who.int/nha/database/ViewData/Indicators/en 


\section{References}

Chisholm, D., Stanciole, A.E., Edejer, T.T.T., \& Evans, D.B. (2010). Economic Impact of Disease and Injury: Counting What Matters. British Medical Journal, 340, 583-586.

East African Community. (2019, June 15). EAC at A Glance. Retrieved from https://www.eac.int/

East African Community. (2015). HIV and AIDS/STI and TB Multisectoral Strategic Plan and Implementation Framework 2015 - 2020. Arusha, Tanzania: East African Community.

Every Woman Every Child. (2015). The Global Strategy for Women's, Children's and Adolescents' Health (2016-2030). New York: Every Woman Every Child. Retrieved from http://globalstrategy.everywomaneverychild.org/

Fein, R. (1958). Economics of Mental Illness. New York, USA: Basic Books.

GBD 2017 Mortality Collaborators. (2018). Global, regional, and national age-sex-specific mortality and life expectancy, 1950-2017: a systematic analysis for the Global Burden of Disease Study 2017. Lancet, 392, 1684-735.

GBD 2017 DALYs and HALE Collaborators. (2018). Global, regional, and national disability-adjusted life-years (DALYS) for 359 diseases and injuries and healthy life expectancy (HALE) for 195 countries and territories, 1990-2017: a systematic analysis for the Global Burden of Disease Study 2017. Lancet, 392, 1859-922.

GBD 2017 Cause of Death Collaborators. (2018). Global, regional, and national age-sex-specific mortality for 282 causes of death in 195 countries and territories, 1980-2017: a systematic analysis for the Global Burden of Disease Study 2017. Lancet, 392, 1736-1788.

GBD 2017 Disease and Injury Incidence and Prevalence Collaborators. (2018). Global, regional, and national incidence, prevalence, and years lived with disability for 354 diseases and injuries for 195 countries and territories, 1990-2017: a systematic analysis for the Global Burden of Disease Study 2017. Lancet, 392, 1789-858.

Giannetti, B.F., Agostinho, F., Almeida, C., \& Huisingh, D. (2015). A review of limitations of GDP and alternative indices to monitor human wellbeing and to manage eco-system functionality. Journal of Cleaner Production, 87, 11-25.

Global Burden of Disease Collaborative Network. (2018). Global Burden of Disease Study 2017 (GBD 2017) Results. Seattle, United States: Institute for Health Metrics and Evaluation (IHME). Retrieved from http://ghdx.healthdata.org/gbd-results-tool.

International Monetary Fund (IMF). (2019, March 5). World economic outlook database. Washington, D.C.: IMF. Retrieved from https://www.imf.org/external/pubs/ft/weo/2018/02/weodata/index.aspx].

Ivković, A.F. (2016). Limitations of the GDP as a measure of progress and well-being. Ekonomski vjesnik /Econviews, XXIX, 1/2016, 257-272.

Jones-Lee, M.W. (1985). The Value of Life and Safety: a Survey of Recent Developments. The Geneva Papers on Risk and Insurance. 10(36),141-173. 
Kirigia, J.M., Muthuri, R.N.D.K., \& Gitonga, N. (2019). Fiscal value of disability-adjusted-life-years lost in the Economic and Monetary Community of Central Africa (CEMAC). International Public Health Journal. 11(12). (In press). Retrieved from http://www.novapublishers.org/catalog/product info.php?products id=66020

Kirigia, J.M., \& Mwabu, G.M. (2018). The Monetary Value of Disability-Adjusted-Life-Years Lost in the East African Community in 2015. Modern Economy, 9, 1360-1377.

Kirigia, J.M. \& Mwabu, G.M. (2018). Haemorrhage of gross domestic product from disability-adjustedlife-years among 15-59 year olds in Kenya. International Archives of Medicine, 11(20). doi: $10.3823 / 2561$

Kirigia, J.M., Mburugu, G.N., \& Huka, G.S. (2017). The Indirect Cost of Disability Adjusted Life Years Lost among the Elderly in Kenya. International Archives of Medicine, 10(213). doi: https://doi.org/10.3823/2483.

Landefeld, J.S., \& Seskin, E.P. (1982). The Economic Value of Life: Linking Theory to Practice. American Journal of Public Health, 72, 555-566.

Lee, Y-R., Cho, B., Jo, M-W., Ock, M., Lee, D., Kim, M.J., \& Oh, I-H. (2019). Measuring the Economic Burden of Disease and Injury in Korea, 2015. J Korean Med Sci, 26, 34 Suppl 1, e80. Retrieved from https://doi.org/10.3346/ikms.2019.34.e80.

Masters, S.H., Burstein, R., DeCenso, B., Moore, K., Haakenstad, A., Ikilezi, G., Achan, J., Osei, I., Garshong, B., Kisia, C., Njuguna, P., Babigumira, J., Kumar, S., Hanlon, M., \& Gakidou, E. (2014). Pharmaceutical Availability across Levels of Care: Evidence from Facility Surveys in Ghana, Kenya, and Uganda. PLOS ONE, 9(12), e114762. Retrieved from https://doi.org/10.1371/journal.pone.0114762

Ministry of Health. (2016). The Kenya Malaria Communication Strategy 2016-2021. Nairobi: National Malaria Control Programme; 2016.

Ministry of Health. (2014). Guidelines for the Treatment of Chronic Hepatitis B and C Viral Infections in Kenya. Nairobi: Ministry of Health.

Ministry of Health. (2012). National Health Promotion Strategy for Kenya-Re-orienting Health (20132018). Nairobi: Ministry of Health.

Mishan, E.J. (1971). Evaluation of life and limb: a theoretical approach. Journal of Political Economy, 79, 687-705.

Murray, C.J.L. (1994). Quantifying the burden of disease: the technical basis for disability-adjusted life years. Bulletin of the World Health Organization, 72(3), 429-445.

Mushkin, S.J., \& Collings, F.A. (1959) Economic Costs of Disease and Injury. Public Health Reports, 74, 795-809. Retrieved from https://doi.org/10.2307/4590578

Muthuri, R.D.K., Muthuri, N.G., \& Kirigia, J.M. (2018). Pecuniary Value of Disability-Adjusted-Life-Years in the Arab Maghreb Union in 2015. Journal of Human Resource and Sustainability Studies, 6, 249274.Retrieved from https://doi.org/10.4236/ihrss.2018.64041

Organisation for Economic Cooperation and Development (OECD). (2001). The well-being of nations the role of human and social capital. Paris, France: OECD. 
Petty, W. (1699). Political Arithmetick, or a Discourse Concerning the Extent and Value of Lands, People, Buildings, Etc. London, UK: Robert Caluel.

Republic of Kenya. (2018a). National strategic plan for tuberculosis, leprosy and lung health 20192023. Nairobi: Ministry of Health.

Republic of Kenya. (2018b). Kenya malaria strategy (KMS) 2019-2023. Nairobi: Ministry of Health. Republic of Kenya. (2018c). Kenya national cancer screening guidelines. Nairobi: Ministry of Health. Republic of Kenya. (2018d). Kenya National Guidelines for Cardiovascular Diseases Management. Nairobi: Ministry of Kenya.

Republic of Kenya. (2018e). National physical activity action plan 2018-2023. Nairobi: Ministry of Health.

Republic of Kenya. (2018f). Kenya national violence and injury prevention and control action plan 2018 - 2022. Nairobi: Ministry of Health.

Republic of Kenya. (2017a). The Health Act No. 21 of 2017. Nairobi: National Council for Law Reporting. Republic of Kenya. (2017b). National cancer control strategy 2017-2022. Nairobi: Ministry of Health. Republic of Kenya. (2017c). National guidelines for healthy diets and physical activity. Nairobi: Ministry of Health.

Republic of Kenya. (2016a). Kenya reproductive, maternal, newborn, child and adolescent health (RMNCAH) investment framework. Nairobi: Ministry of Health.

Republic of Kenya. (2016b). Kenya mental health policy 2015 - 2030. Nairobi: Ministry of Health.

Republic of Kenya. (2015a). The $2^{\text {nd }}$ Kenya national strategic plan for control of neglected tropical diseases 2016-2020. Nairobi: Ministry of Health.

Republic of Kenya. (2015b). Kenya national strategy for the prevention and control of noncommunicable diseases 2015 - 2020. Nairobi: Ministry of Health.

Republic of Kenya. (2015c). National road safety action plan 2015 - 2020. Nairobi.

Republic of Kenya. (2014a). Kenya AIDS strategic framework 2014/2015 - 2018/2019. Nairobi: Ministry of Health.

Republic of Kenya. (2014b). The Kenya health policy 2014-2030. Nairobi: Ministry of Health.

Republic of Kenya. (2014c). Kenya health sector strategic and investment plan, 2013-2017. Nairobi: Ministry of Health.

Republic of Kenya. (2014d). National Transport and Safety Authority Act No. 33 of 2012. Nairobi: National Council for Law Reporting.

Republic of Kenya. (2013). 2012/2013 Kenya national housing survey. Basic report. Nairobi: Ministry of Land, Housing \& Urban Development.

Republic of Kenya. (2012a). Public Health Act CAP. 242. Nairobi: National Council for Law Reporting. Republic of Kenya. (2012b). HIV and AIDS Prevention and Control Act No. 14 of 2006. [Rev. 2012]. Nairobi: National Council for Law Reporting. 
Republic of Kenya. (2012c). The Sexual Offences Act No. 3 of 2006, Act No. 7 of 2007, Act No. 6 of 2009, Act No. 8 of 2010, Act No. 12 of 2012. Nairobi: National Council for Law Reporting.

Republic of Kenya. (2012d). Malaria prevention Act CAP. 246. Nairobi: National Council for Law Reporting.

Republic of Kenya. (2012e). Kenya's national nutrition action plan 2012-2017. Nairobi: Ministry of Health.

Republic of Kenya. (2012f). The Cancer Prevention and Control Act, 2012. Nairobi: Republic of Kenya.

Republic of Kenya. (2012g). Tobacco Control Act, 2007. Nairobi: National Council for Law Reporting. Republic of Kenya. (2012h). Alcoholic Drinks Control Act, 2010. Nairobi: National Council for Law Reporting.

Republic of Kenya. (2012i). Births and deaths registration ACT chapter 149. Nairobi: National Council for Law Reporting.

Republic of Kenya. (2010a). National road map for accelerating the attainment of the MDGs related to maternal and newborn health in Kenya. Nairobi: Ministry of Health.

Republic of Kenya. (2010b). Kenya national diabetes strategy 2010-2015. Nairobi: Ministry of Health.

Republic of Kenya. (2010c). The constitution of Kenya, 2010. Nairobi: National Council for Law Reporting.

Republic of Kenya. (2009). Integrated national transport policy: moving a working nation. Ministry of Transport.

Schofield, D., Cunich, M., Shrestha, R., Passey, M., Veerman, L., Tanton, R., \& Kelly, S. (2019). The indirect costs of ischemic heart disease through lost productive life years for Australia from 2015 to 2030: results from a microsimulation model. BMC Public Health, 19, 802. Retrieved from https://doi.org/10.1186/s12889-019-7086-5

Scholten, A.C., Haagsma, J.A., Panneman, M.J.M., van Beeck, E.F., \& Polinder, S. (2014). Traumatic Brain Injury in the Netherlands: Incidence, Costs and Disability Adjusted Life Years. PLOS ONE, 9(10), e110905. Retrieved from https://doi.org/10.1371/journal.pone.0110905

Stenberg, K., Hanssen, O., Edejer, T.T.T., Bertram, M., Brindley, C., Meshreky, A., Rosen, J.E., Stover, J., Verboom, P., Sanders, R., \& Soucat, A. (2017). Financing Transformative Health Systems towards Achievement of the Health Sustainable Development Goals: A Model for Projected Resource Needs in 67 Low-Income and Middle-Income Countries. Lancet Glob Health, 5(9), e875-e887.

Stiglitz, J. E., Sen A., \& Fitttousi, J. P. (2009, July 17), "Report by the Commission on the Measurement of Economic Performance and Social Progress". Retrieved from https://ec.europa.eu/eurostat/documents/118025/118123/Fitoussi+Commission+report

Tachkov, K., Kamusheva, M., Pencheva, V., \& Mitov, K. (2017). Evaluation of the economic and social burden of chronic obstructive pulmonary disease (COPD). Biotechnology \& Biotechnological Equipment, 31(4), 855-861. Retrieved from https://doi.org/10.1080/13102818.2017.1335616.

United Nations Development Programme (UNDP). (2018). Human Development Indices and Indicators: 2018 Statistical Update. New York, USA: UNDP. 
United Nations Organization (UN). (2018a). Consolidating gains and accelerating efforts to control and eliminate malaria in developing countries, particularly in Africa, by 2030. General Assembly Resolution A/RES/72/309. New York, USA: UN.

UN. (2018b). Political declaration of the high-level meeting of the General Assembly on the fight against tuberculosis. United Nations General Assembly Resolution A/RES/73/3. New York, USA: UN.

UN. (2018c). Political declaration of the third high-level meeting of the General Assembly on the prevention and control of non-communicable diseases. United Nations General Assembly Resolution A/RES/73/2. New York, USA: UN.

UN. (2018d). Improving global road safety. United Nations General Assembly Resolution A/RES/72/271. New York, USA: UN.

UN. (2017a). The girl child. General Assembly Resolution A/RES/72/154. New York, USA: UN.

UN. (2017b). The right to food. General Assembly Resolution A/RES/72/173. New York, USA: UN.

UN. (2017c). The human rights to safe drinking water and sanitation. United Nations General Assembly Resolution A/RES/72/178. New York, USA: UN.

UN. (2016a). Political Declaration on HIV and AIDS: On the Fast Track to Accelerating the Fight against HIV and to Ending the AIDS Epidemic by 2030. General Assembly Resolution A/RES/70/266. New York, USA: UN.

UN. (2016b). Improving global road safety. United Nations General Assembly Resolution A/RES/70/260. New York, USA: UN.

UN. (2015). Transforming our world: the 2030 Agenda for Sustainable Development. Seventieth session of the United Nations General Assembly Resolution A/RES/70/1. New York, USA: UN.

UN. (2012). Political Declaration of the High-level Meeting of the General Assembly on the Prevention and Control of Non-communicable Diseases. UNGA resolution A/RES/66/2. New York, USA: UN.

UN. (2010). Improving global road safety. UNGA resolution A/RES/64/255. New York, USA: UN.

UNICEF. (2007). How to calculate Average Annual Rate of Reduction (AARR) of Underweight Prevalence. Statistics and Monitoring Section/Division of Policy and Practice Technical Note. New York, USA: UNICEF.

Weisbrod, B.A. (1971). Costs and Benefits of Medical Research: A Case Study of Poliomyelitis. Journal of Political Economy, 79, 527-544. Retrieved from https://doi.org/10.1086/259766

World Health Organization (WHO). (2019a). World health statistics overview 2019: monitoring health for the SDGs, sustainable development goals. Geneva: WHO.

WHO. (2019b, July 3). Global Health Expenditure Database. Geneva: WHO. Retrieved from http://apps.who.int/nha/database/ViewData/Indicators/en

WHO. (2019c). A heavy burden: the productivity cost of illness in Africa. Brazzaville: WHO Regional Office for Africa (WHO/AFRO).

WHO. (2018a). WHO global action plan on physical activity 2018-2030. WHA Resolution WHA71.6. Geneva: WHO.

WHO. (2018b). Infant and young child feeding. Resolution WHA71.9. Geneva: WHO. 
WHO. (2018c). Rheumatic fever and rheumatic heart disease. Resolution WHA71.14. Geneva: WHO.

WHO. (2017a). Global atlas of medical devices. World Health Organization. Geneva: WHO.

WHO. (2017b). World malaria report 2017. Geneva: World Health Organization.

WHO. (2017c). Global tuberculosis report 2018. Geneva: WHO.

WHO. (2017d). Global vector control response 2017-2030. Geneva: WHO.

WHO. (2017e). Strengthening immunization to achieve the goals of the global vaccine action plan. Resolution WHA70.14. Geneva: WHO.

WHO. (2017f). Global vector control response: an integrated approach for the control of vector-borne diseases. Resolution. WHA70.16. Geneva: WHO.

WHO. (2017g). Cancer prevention and control in the context of an integrated approach. Resolution WHA70.12. Geneva: WHO.

WHO. (2016a). Global Health Sector Strategy on HIV 2016-2021: Towards Ending AIDS. The Sixty-Ninth World Health Assembly Document A69/31. Geneva: WHO.

WHO. (2016b). Global Health Sector Strategy on Viral Hepatitis, 2016-2021. Geneva: WHO.

WHO. (2015a). Global technical strategy for malaria 2016-2030. Geneva: WHO.

WHO. (2015b) The end TB strategy. Geneva: WHO.

WHO. (2013). Global action plan for the prevention and control of noncommunicable diseases 20132020. Geneva: WHO.

WHO. (2009). WHO Guide to Identifying the Economic Consequences of Disease and Injury. Geneva: WHO.

WHO. (2006). Health financing: a strategy for the African region. WHO Regional Committee for Africa resolution AFR/RC56/R5. Brazzaville: WHO/AFRO.

WHO. (2000). Global strategy for the prevention and control of noncommunicable diseases. Geneva: WHO. 
Figures 


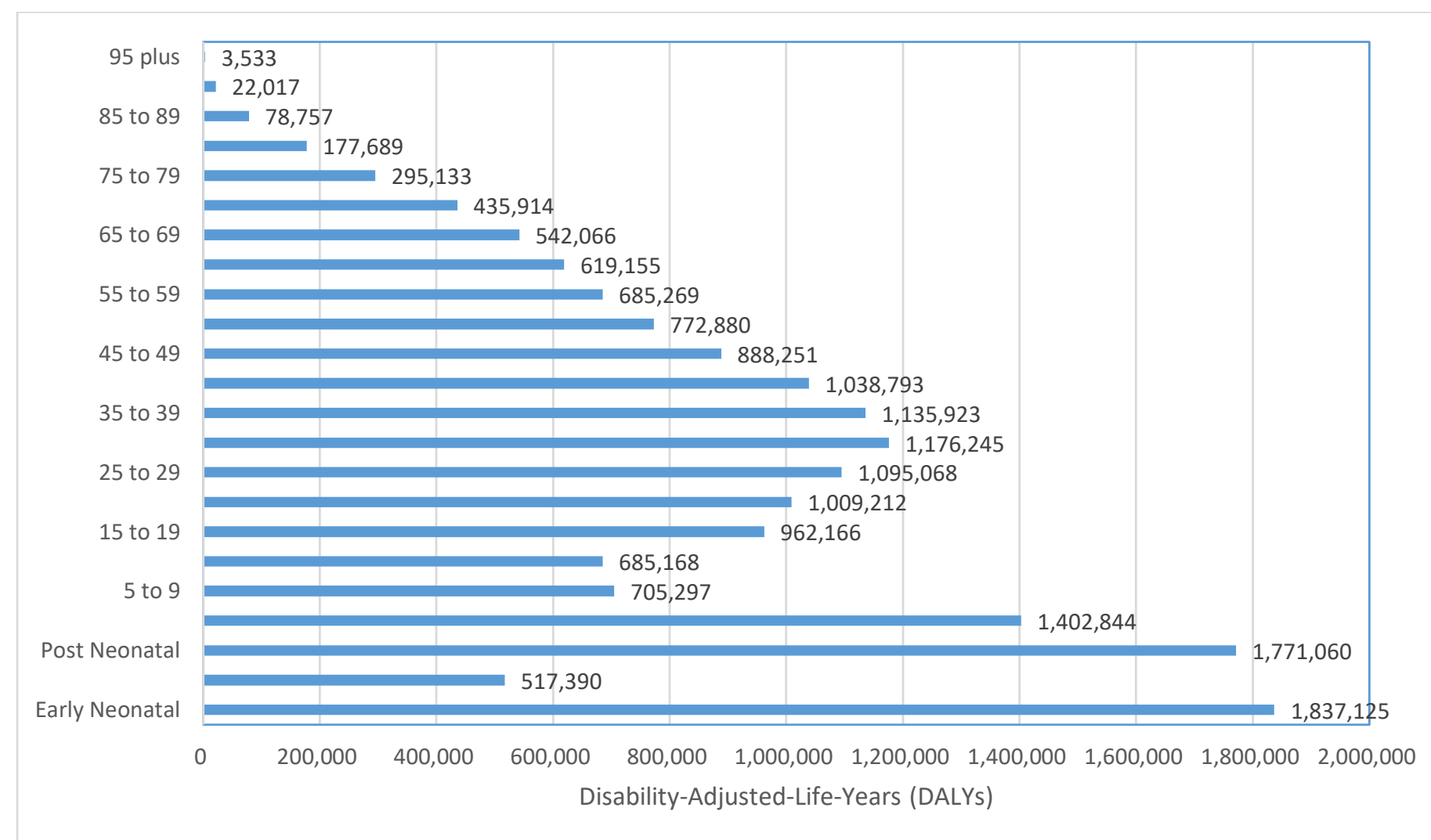

Figure 1: Disability-Adjusted-Life-Years (DALY) lost from all causes in Kenya in 2017 


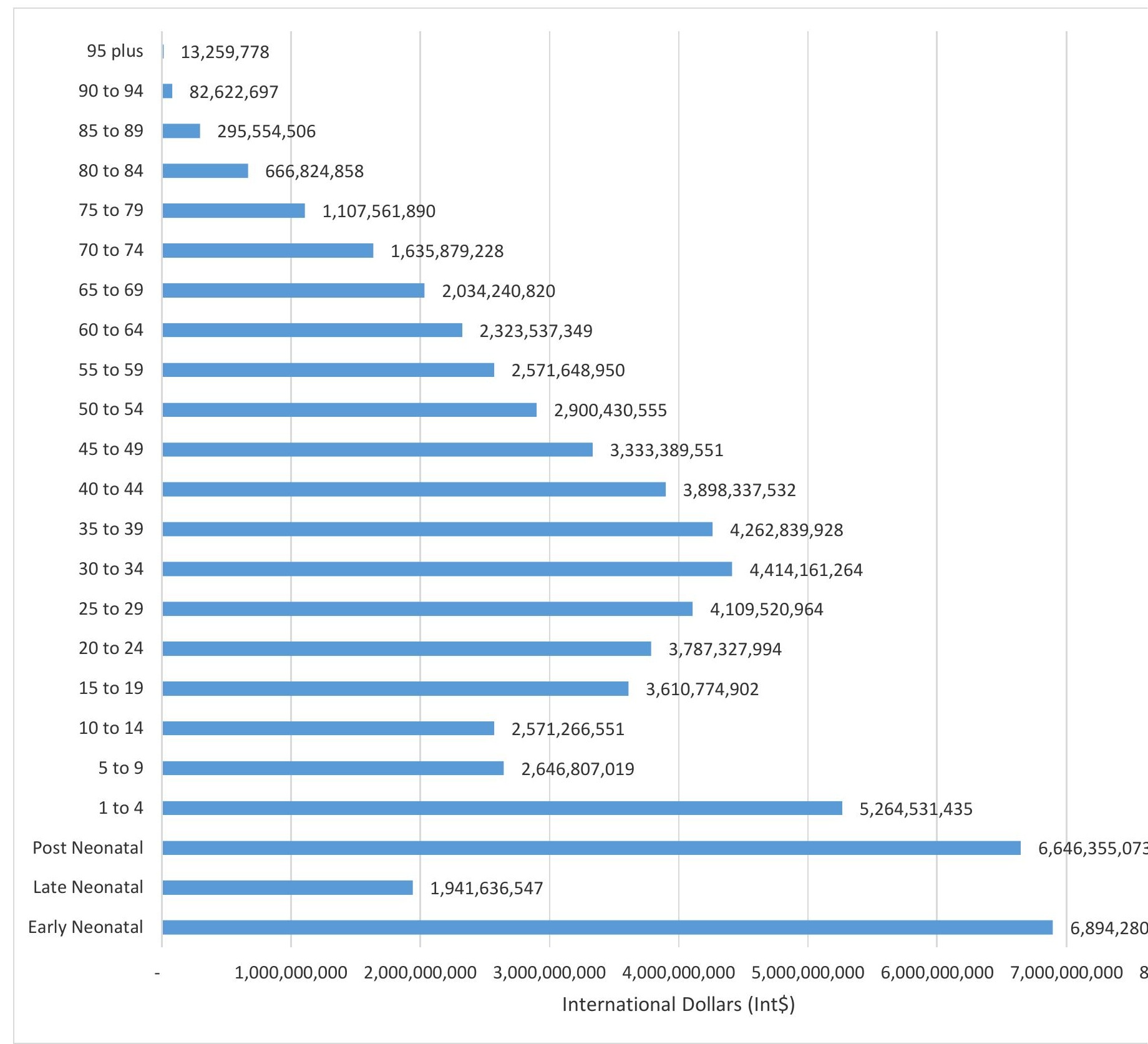

Figure 2: Distribution of the monetary Value of DALYs lost from all causes by age groups in Kenya (2019 Int\$ or PPP) 


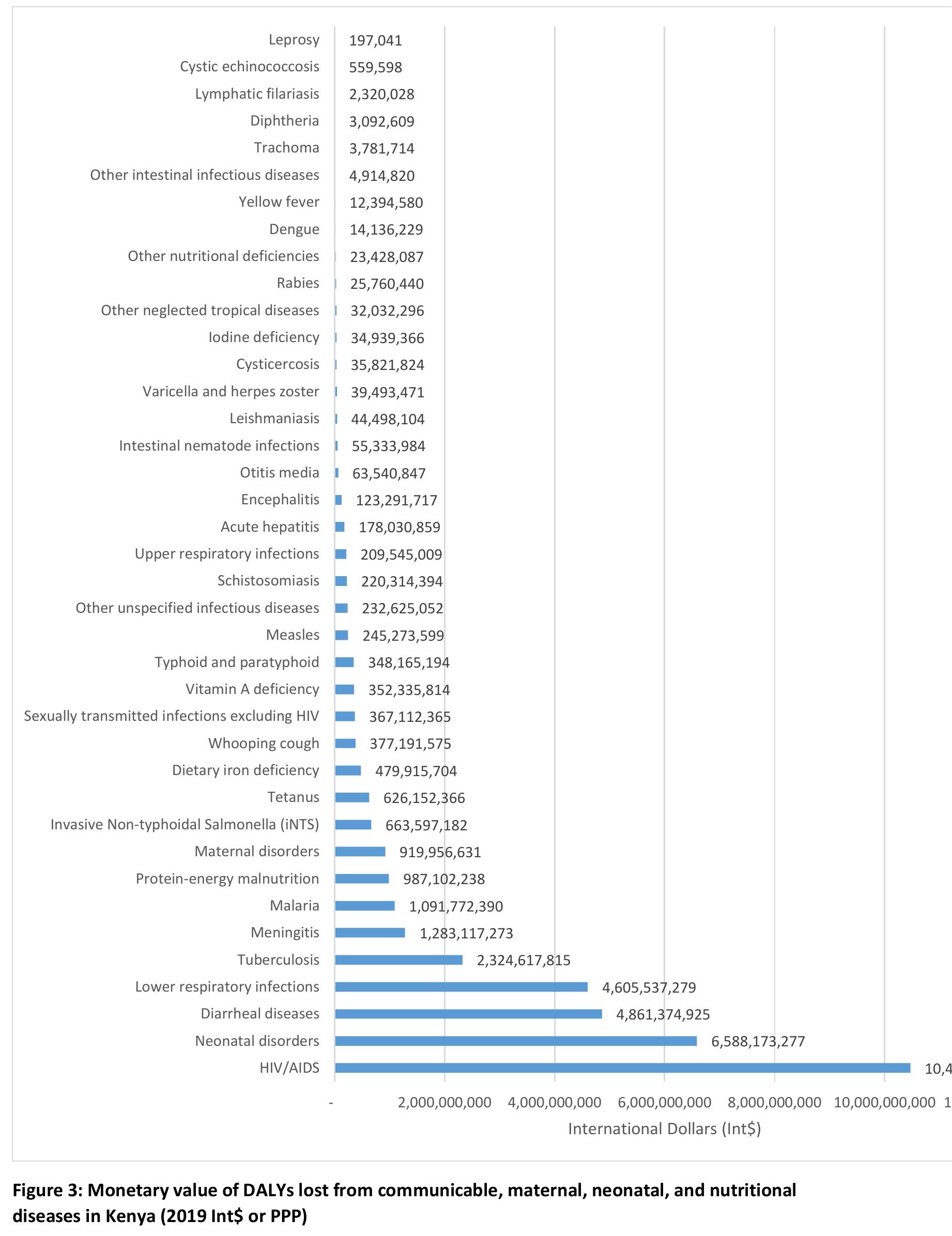




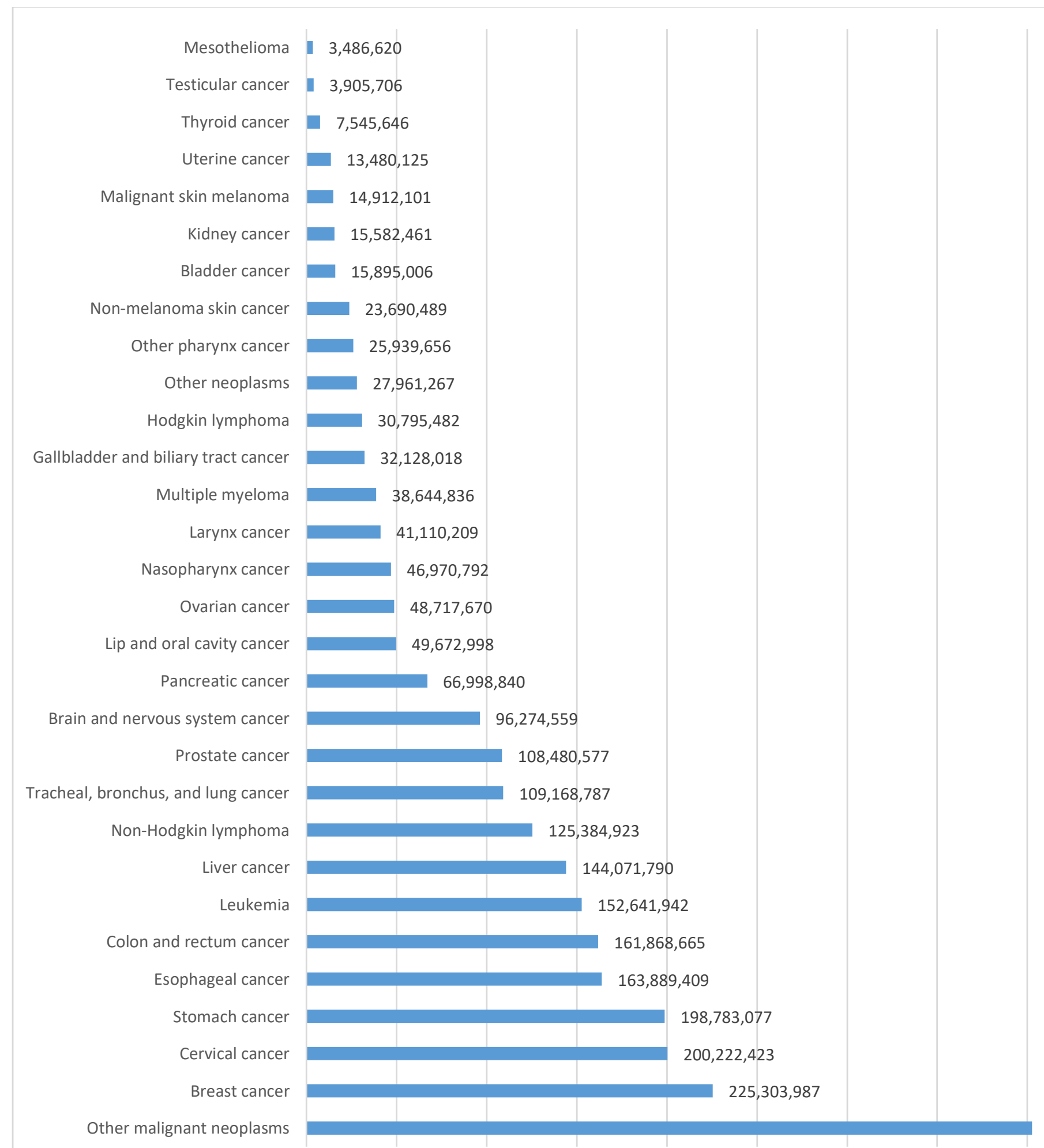

$50,000,000$ 100,000,000150,000,000200,000,000250,000,000300,000,000350,000,000400,000,00 International Dollars (Int\$)

Figure 4: Monetary value of DALYs lost from neoplasms (cancer) in Kenya (2019, Int\$ or PPP) 


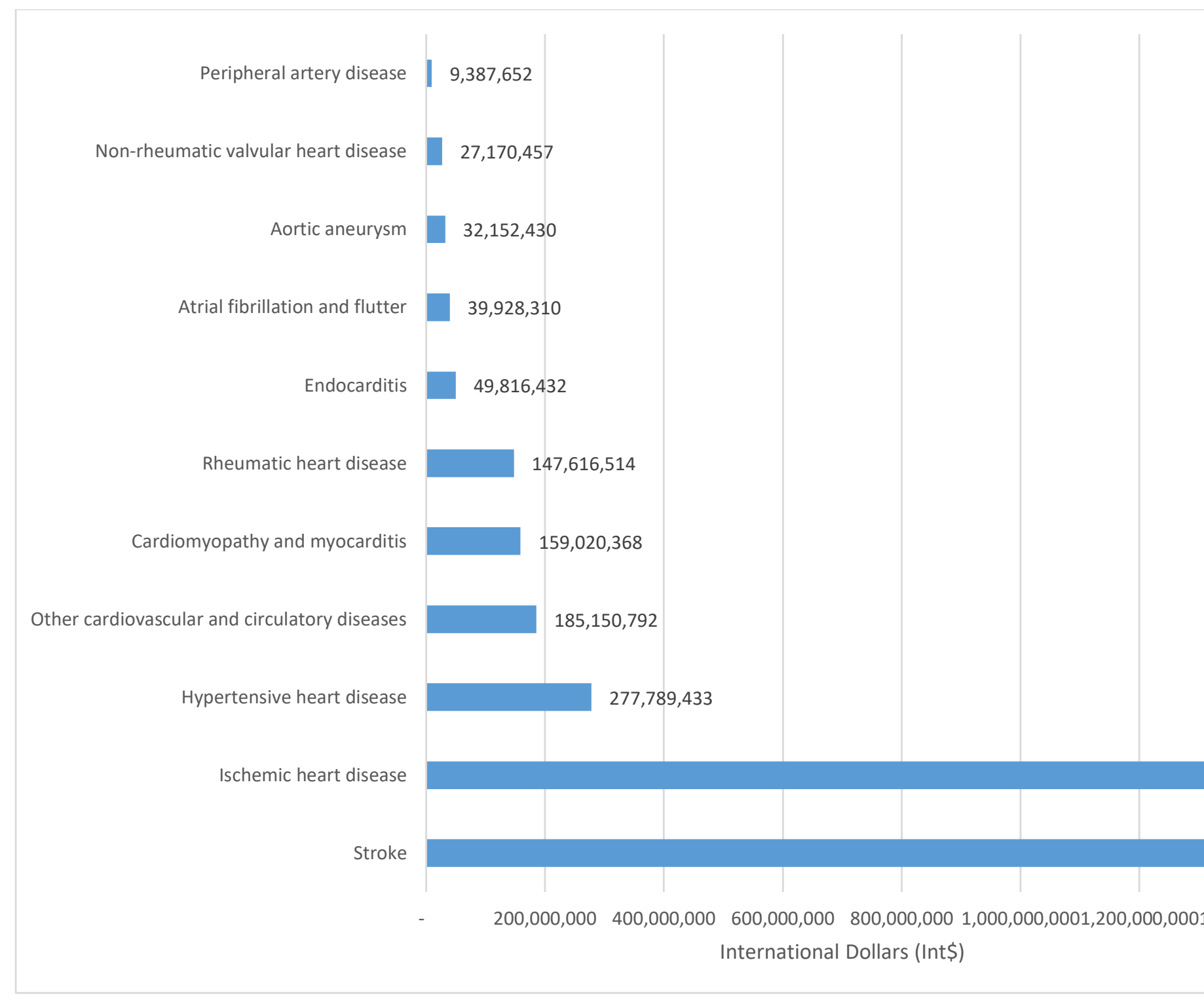




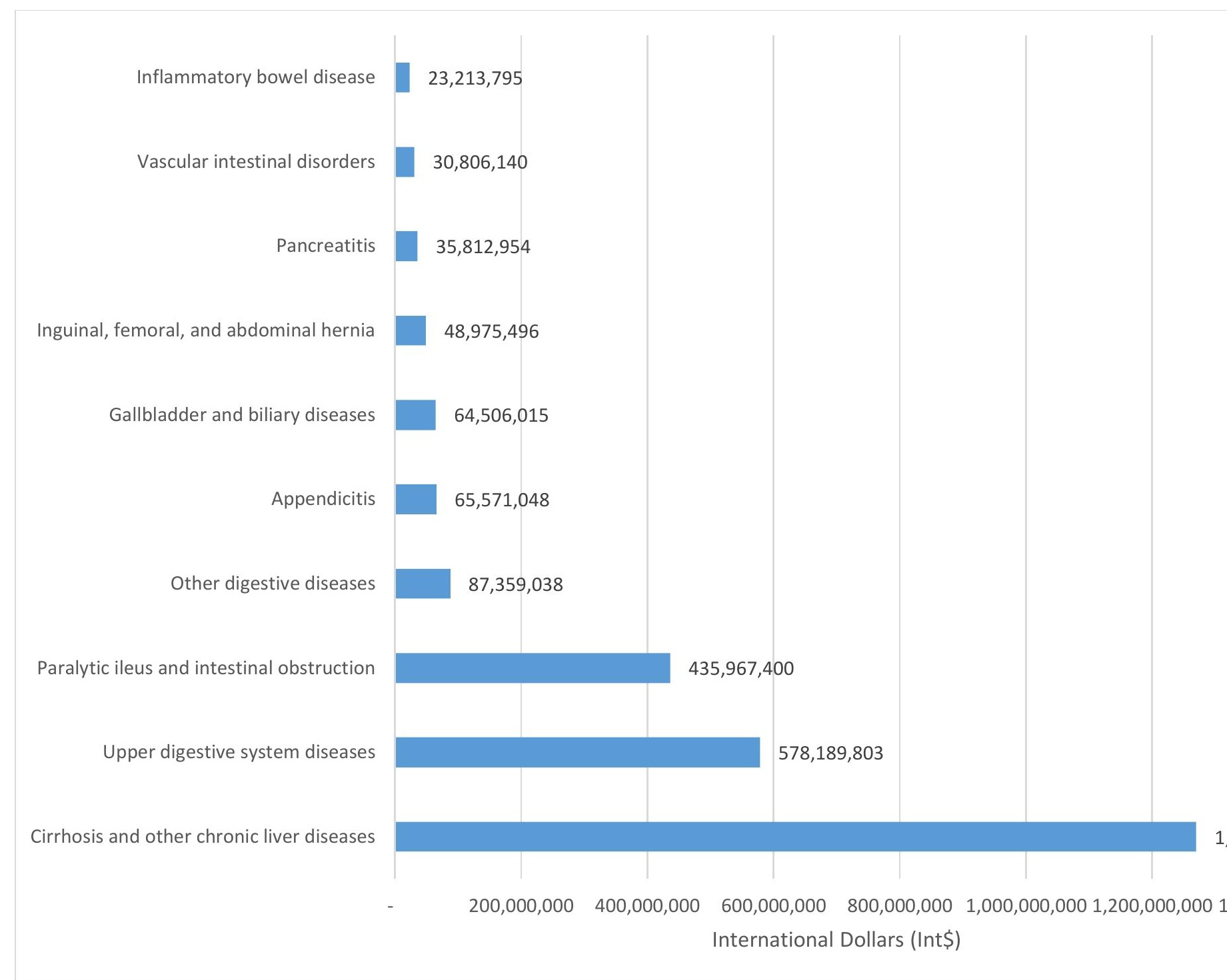

Figure 6: Monetary value of DALYs lost from digestive diseases in Kenya (2019 Int\$ or PPP) 


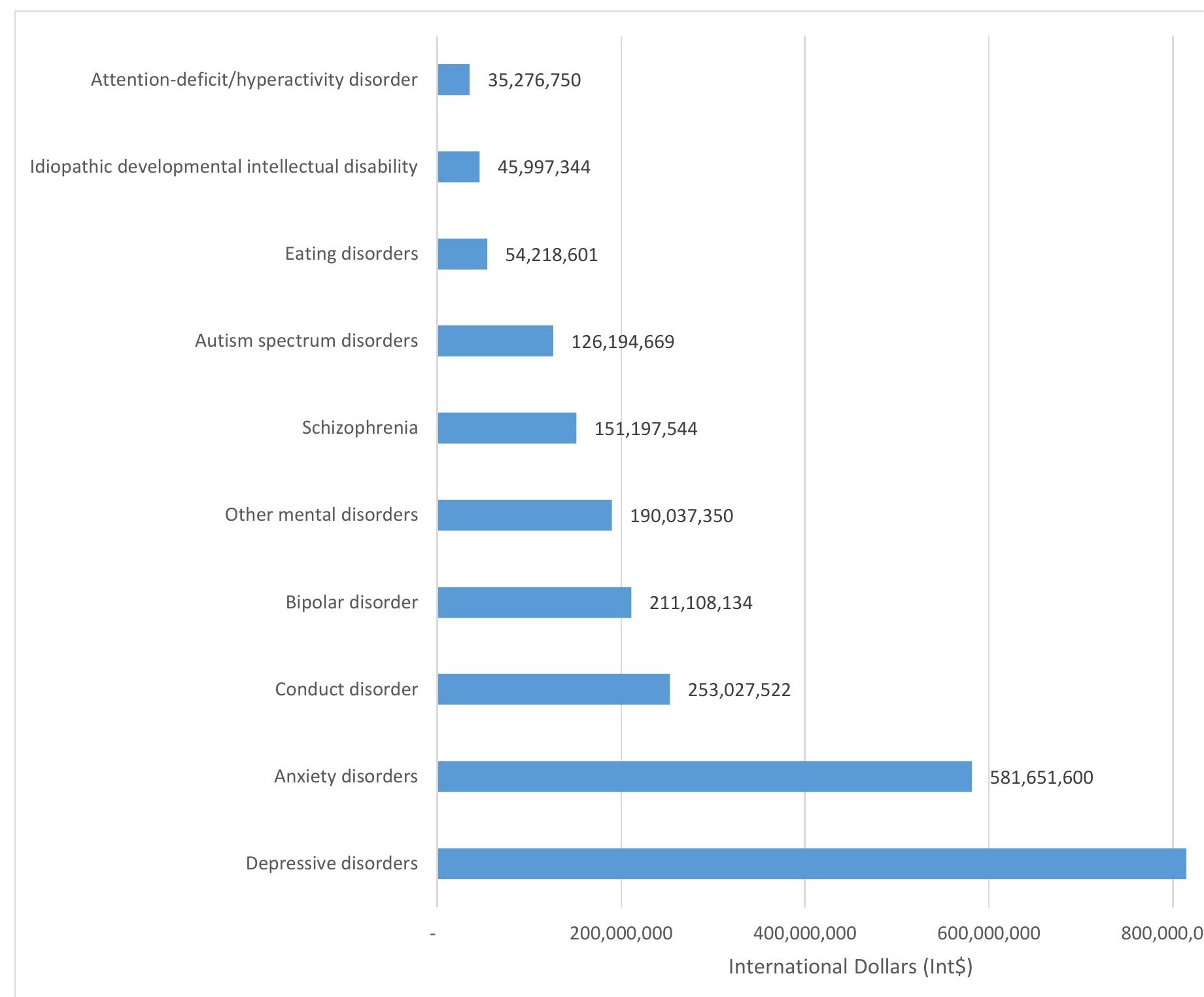

Figure 7: Monetary value of DALYs lost from mental disorders in Kenya (2019 Int\$ or PPP) 


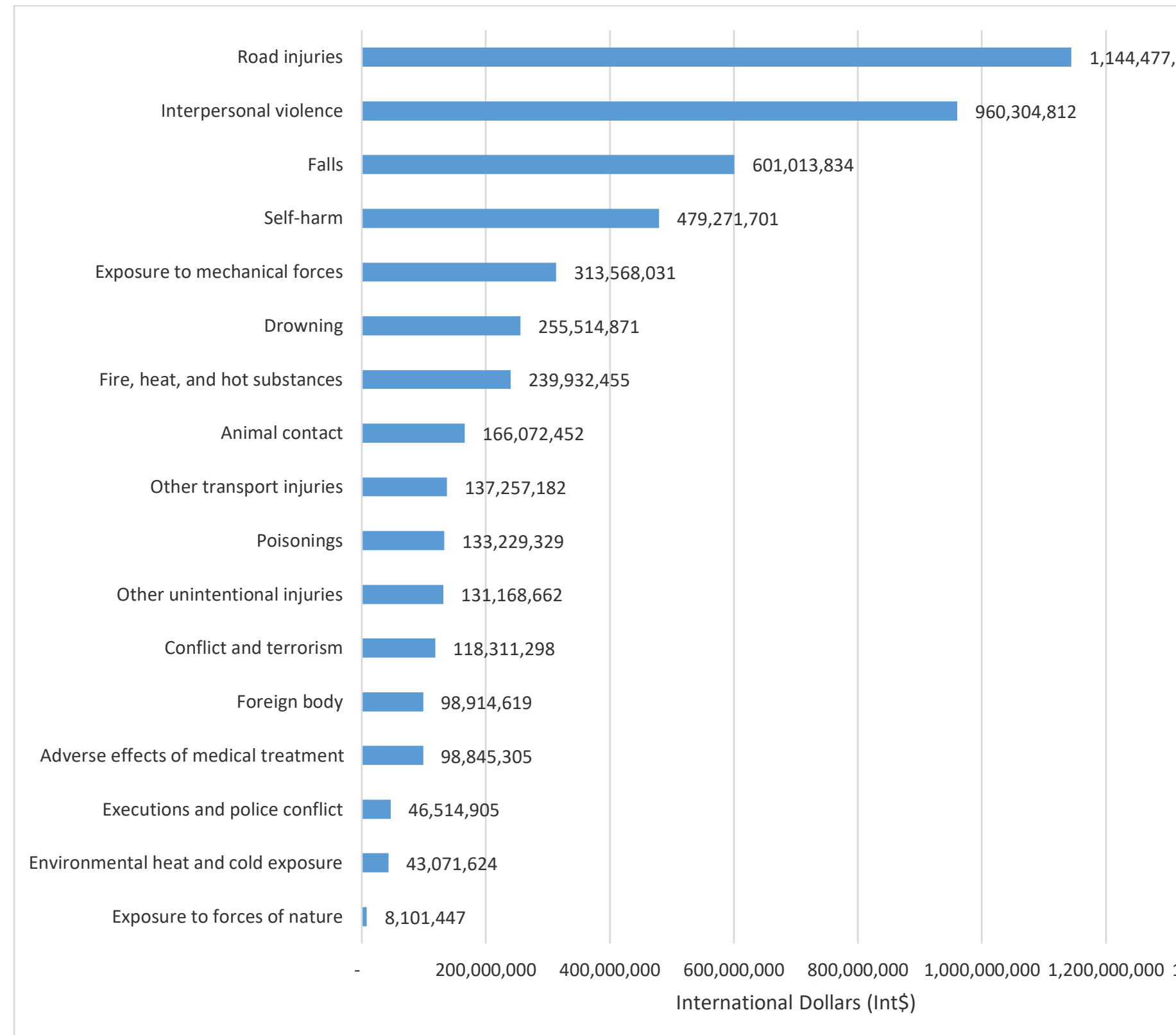

Figure 8: Monetary Value of DALYs lost from injuries in Kenya (2019 Int\$ or PPP) 